This manuscript is a preprint. Although it has undergone peer-review, it has yet to be accepted. Subsequent versions of this manuscript may thus have different content. If accepted, the final version of this manuscript will be available via the 'Peer-reviewed Publication DOI' link on the right-hand side of this webpage. Please feel free to contact any of the authors directly or to comment on the manuscript using hypothes.is (https://web.hypothes.is/). We welcome feedback! 


\title{
The Stratigraphic Record of Minibasin Subsidence, Precaspian Basin, Kazakhstan
}

Christopher A-L. Jackson ${ }^{1 *}{ }^{\infty}$
Oliver B. Duffy
Naiara Fernandez
Tim P. Dooley
Michael R. Hudec

Martin P.A. Jackson
George Burg

${ }^{1}$ Bureau of Economic Geology, Jackson School of Geoscience, University of Texas at Austin, University Station, Box X, Austin, Texas, 78713-8924, USA

\author{
${ }^{2}$ Condor Petroleum Inc, Suite 2400, 144-4 $4^{\text {th }}$ Ave SW, Calgary, AB, T2P 3N4, Canada \\ *present address: Basins Research Group (BRG), Department of Earth Science and Engineering, \\ Imperial College, Prince Consort Road, London, SW7 2BP, UK \\ ${ }^{\infty}$ corresponding author: c.jackson@imperial.ac.uk (C.A-L. Jackson)
}

\section{ABSTRACT}

Minibasins are fundamental components of many salt-bearing sedimentary basins, where they may host large volumes of hydrocarbons. Although we understand the basic mechanics governing their subsidence, we know surprisingly little of how minibasins subside in three-dimensions over geological timescales, or what controls such variability. Such knowledge would improve our ability to constrain initial salt volumes in sedimentary basins, the timing of salt welding, and the distribution and likely charging histories of suprasalt hydrocarbon reservoirs. We use 3D seismic reflection data from the Precaspian Basin, onshore Kazakhstan to reveal the subsidence histories of 16, Upper Permian-toTriassic, suprasalt minibasins. These minibasins subsided into a Lower-to-Middle Permian salt layer that contained numerous relatively strong, clastic-dominated minibasins encased during an earlier, latest Permian phase of diapirism; because of this, the salt varied in thickness. Suprasalt minibasins contain a stratigraphic record of symmetric (bowl-shaped units) and then asymmetric (wedge-shaped units) subsidence, with this change in style seemingly occurring at different times in different minibasins, and most likely prior to welding. We complement our observations from natural minibasins in the Precaspian Basin with results arising from new physical sandbox models; this allows us to explore the 
potential controls on minibasin subsidence patterns, before assessing which of these might be applicable to our natural example. We conclude that due to uncertainties in the original spatial relationships between encased and suprasalt minibasins, and the timing of changes in style of subsidence between individual minibasins, it is unclear why such complex temporal and spatial variations in subsidence occur in the Precaspian Basin. Regardless of what controls the observed variability, we argue that vertical changes in minibasin stratigraphic architecture may not record the initial (depositional) thickness of underlying salt or the timing of salt welding; this latter point is critical when attempting to constrain the timing of potential hydraulic communication between sub-salt source rocks and suprasalt reservoirs. Furthermore, temporal changes in minibasin subsidence style will likely control suprasalt reservoir distribution and trapping style.

\section{INTRODUCTION}

A minibasin is defined as a "synkinematic basin subsiding into relatively thick autochthonous or allochthonous salt" (Jackson and Talbot, 1991, p.16; Fig. 1). Minibasins are fundamental components of many salt-bearing sedimentary basins and are remarkable in that, despite their relatively small size (typically a few kilometres to tens of kilometres in diameter; Fig. 1B, C and E), they can subside faster (>1-10 km/Myr) than basins formed on continental or oceanic crust (e.g. Worrall and Snelson, 1989; Prather, 2000). Due to their rapid subsidence rates and widespread development in some of the world's largest salt basins (e.g. Gulf of Mexico, Precaspian Basin, circum-South Atlantic; Hudec and Jackson, 2007), minibasins act as repositories for vast quantities of continent-derived sediment. Significant volumes of hydrocarbons may also be contained within minibasins, with their style of subsidence controlling the distribution of reservoir rocks and trap style (Fig. 1D) (e.g. Prather, 2000; Kane et al., 2012). More generally, minibasin stratigraphic architecture may record the processes controlling basin subsidence and, more fundamentally, the thickness of underlying salt and the timing of salt welding (Fig. 1A) (Rowan and Weimer, 1998). Constraining past and present salt thicknesses (and hence, volumes) is a key challenge when attempting to unravel the geodynamics of continental breakup (e.g. Davison et al., 2012), whereas the timing of salt welding is of critical importance for understanding the potential for and the timing of the transmission of hydrocarbons through welds from subsalt source rocks into suprasalt reservoirs (Rowan, 2004).

Despite their ubiquity and importance, and although they are typically well-imaged in seismic reflection data and penetrated by numerous boreholes, surprisingly little is known about the variability of minibasin subsidence, and what controls this in time and space (see Clark et al. 1998 for an exception; Fig. 1E). This reflects how few published studies have employed high-quality, regionally-extensive 3D seismic reflection datasets to map their synkinematic strata, the architecture of which preserve a record of salt tectonic-related changes in accommodation. Using 2D seismic reflection and borehole data from 
packages within Pliocene-Pleistocene minibasins subsiding into thick allochthonous salt. Each type defines a different style of minibasin subsidence, with periods of broadly symmetrical subsidence recorded by 'bowls' and 'layers', and asymmetric subsidence and minibasin tilting defined by 'wedges' (Fig. 1A and C). Rowan and Weimer (1998) conclude the transition from bowl- to wedge-shaped packages is driven by and thus records, minibasin welding during passive diapirism (see Fig. 1A; see also Kergaravat et al., 2017). Quirk \& Pilcher (2012) also use 2D seismic data to document deposition of seismic-scale, wedge-shaped packages overlying packages that are, in detail, tabular (i.e. prekinematic; see their figure 4) rather than truly bowl-shaped. They infer the wedges do not document welding, but instead are growth strata deposited prior to welding, in the hangingwalls of normal faults accommodating thin-skinned extension. Hudec et al. (2009), using 2D profiles extracted from 3D seismic reflection datasets, also show that variations in minibasin stratigraphic architecture may not simply document welding; rather, they infer offset stacking of bowl-shaped packages may document: (i) minibasin genesis and subsequent subsidence under the influence of sedimentary topographic loading (see also Ge et al., 1997 and Jackson et al., 2015); (ii) syn-subsidence regional shortening; and/or (iii) horizontal translation of a minibasin array within a spreading canopy (e.g. Fig. 1D). Essentially two-dimensional exposures of minibasins in the field also reveal temporal changes in subsidence patterns, recorded by the deposition of bowl- and then offset-stacked, wedge-shaped stratigraphic units (e.g. Kergaravat et al., 2017; Teixell et al., 2017). Given that salt flow can be very three-dimensional, even in cases defined by simple minibasin downbuilding and passive diapirism, it is unlikely that simple two-dimensional seismic profiles or exposures capture the true temporal and spatial complexity of minibasin subsidence (see Fig. 1E and F).

In this paper we consider the following three questions: (i) what are the key styles of stratigraphic architectures developed in minibasins?; (ii) what controls minibasin subsidence patterns?; and (iii) how do variations in minibasin subsidence impact hydrocarbon exploration in salt-bearing sedimentary basins? To answer these questions, we use high-quality 3D seismic reflection and borehole data to constrain subsidence patterns in 16 minibasins in the eastern Precaspian Basin, onshore Kazakhstan. The Precaspian Basin is an ideal place to conduct this study because: (i) the minibasins contain a thick (up to $5.5 \mathrm{~km}$ ) stratigraphic fill documenting periods of distinct subsidence style during simple downbuilding and passive diapirism; (ii) the minibasins are shallowly buried $(<1 \mathrm{~km})$ beneath a structurally and stratigraphically simple cover and, as a result, are well-imaged in seismic reflection data; (iii) borehole data constrain the composition of underlying salt, indicating this contains a series of clastic-dominated, largely encased minibasins (Duffy et al., 2017; Fernandez et al., 2017). We show that subsidence patterns within and between adjacent minibasins can be complex, with an initial phase of symmetric subsidence (recorded by deposition of bowl-shaped units typically followed by a phase of asymmetric subsidence recorded by deposition of wedge-shaped units). This change in subsidence style likely occurred at different times in different minibasins, and, critically, prior to minibasin welding to presalt strata. Based on the regional geological setting of the Precaspian Basin, in addition to results 
111 arising from new physical sandbox models, we explore a range of mechanisms that could drive the 112 observed subsidence patterns in natural minibasins. The physical models are especially powerful, 113 allowing us to systematically investigate how changes in salt thickness, related to base-salt relief and 114 related variations in salt thickness, might impact minibasin subsidence patterns (cf. Callot et al., 2016).

115 We conclude by discussing the implications of our study for hydrocarbon exploration in salt-bearing 116 sedimentary basins.

\section{TECTONO-STRATIGRAPHIC FRAMEWORK}

The study area is located in the southeastern Precaspian Basin, onshore Kazakhstan (Fig. 2). In the Early Devonian, the Precaspian Basin was part of a SE-dipping passive margin facing the Ural Ocean (Barde et al., 2002a,b; Volozh et al., 2003). Subsequent Middle Devonian rifting was followed by Carboniferous post-rift thermal subsidence. By the middle Carboniferous, collision of the Eastern European and Kazakh plates resulted in the Ural Orogeny, causing uplift of the Precaspian Basin's eastern flank (Brunet et al., 1999; Barde et al., 2002b). By the end of the Early Permian, the Precaspian Basin was represented by a rapidly subsiding foreland basin located in the Uralian foreland. During this time, the basin became isolated from the Tethys Ocean, and a thick (up to $4.5 \mathrm{~km}$ in the basin; c. $2 \mathrm{~km}$ in the study area; Fig. 2B ), Kungurian-to-Kazanian salt sequence was deposited, which passed laterally into clastic and carbonate rocks at the basin margins (Fig. 3) (Gralla and Marsky, 2000; Barde et al., 2002b, Volozh et al., 2003). During the Late Permian, clastic detritus was shed off the rising Ural Mountains, loading the salt and expelling it basinward towards the west. Salt flow resulted in the formation of broadly $\mathrm{N}$-trending salt walls and related expulsion rollovers, both of which were orientated sub-parallel to the local basin margin (Fig. 2C ). Farther west, within our study area, salt walls display an overall polygonal arrangement; individual walls are up to $20 \mathrm{~km}$ long, $8 \mathrm{~km}$ wide, have a vertical relief of up to $5.5 \mathrm{~km}$ (Figs 2, 4A and 5), and bound sub-circular minibasins (Duffy et al., 2017; Fernandez et al., 2017).

Relatively little has been published on the detailed salt-tectonic history of the Precaspian Basin (e.g. Sokolova et al., 1973; Gralla and Marsky, 2000; González Muñoz et al., 2001; Barde et al., 2002a,b; Volozh et al., 2003a,b; Duffy et al., 2017; Fernandez et al., 2017). However, recent work by Duffy et al. (2017) and Fernandez et al. (2017) using data from onshore Kazakhstan show that, during the latest Permian, a series of minibasins subsided into the Lower-to-Middle Permian salt (Fig. 3). These evaporite- and non-marine clastic-bearing minibasins (see Barde et al. 2002b) are now fully or partly encased in the salt, and are typically welded to presalt strata (Figs 4 and 5). They are sub-circular to ovate in plan-view and up to $3000 \mathrm{~m}$ thick, with the thinnest encased minibasins $(<1000$ meters thick) clustering near and commonly being in direct contact with suprasalt minibasins (see below) across 'tertiary' welds (Fig. 5) (sensu Jackson and Cramez, 1989). Thicker encased minibasins are typically located either in the centres (i.e. the large encased basin in the north-western diapir in Fig. 5) or at the 
margins of the host diapirs; in the latter case, they may be welded to suprasalt minibasins (i.e. the two encased minibasins in the right-hand diapir in Fig. 5). Minibasin encasement most likely occurred due to canopy emplacement driven by salt expulsion from beneath adjacent, more rapidly subsiding minibasins, although other mechanisms are possible (see Fig. 3 in Fernandez et al., 2017). Regardless of their origin, the presence of encased minibasins means the salt varied in thickness during subsidence of the suprasalt minibasins, being relatively thin above encased basins, and thick within intervening diapiric feeders that fed the canopy (Fig. 5).

Another generation of minibasins formed in the latest Permian to Triassic (Fig. 3). These suprasalt minibasins are up to $10 \mathrm{~km}$ in diameter and $5.5 \mathrm{~km}$ deep, and are welded to presalt strata or encased minibasins (see above) (Figs 4 and 5) (see also Duffy et al., 2017). A top Permian disconformity , which cannot be identified in seismic reflection data and which may represent a depositional hiatus, is preserved within the suprasalt minibasins; this may record regional shortening related to the protracted, polyphase, Uralian Orogeny (Fig. 3) (Sokolova et al., 1973; Barde et al., 2002a; Volozh et al., 2003). The structural style, stratigraphic architecture, and subsidence history of these suprasalt minibasins form the focus of our study. We do not consider the detailed sedimentology of the suprasalt minibasins because they have not been drilled within the study area (i.e. deep-penetrating wells have targeted the deeper, encased minibasins, thus have drilled overlying thick salt rather than the flanking suprasalt minibasins).

Triassic strata within the suprasalt minibasins are capped by the Base Jurassic Unconformity (BJU; Figs 3 and 5), a major erosional unconformity recording ca. $35 \mathrm{Myr}$ of uplift and erosion associated with the Late Triassic Cimmerian orogeny (e.g. Volozh et al., 2003a; Ismail-Zadeh et al., 2008). This major tectonic event uplifted the Precaspian Basin, resulting in erosion of the crests of salt diapirs and the upper parts of adjacent suprasalt minibasins (Figs 3 and 5). A relatively thin $(<1 \mathrm{~km}$ ), broadly tabular, Jurassic-to-Lower Cretaceous succession caps the diapirs and flanking minibasins (Figs 2 and 5). Regional shortening in the Late Cretaceous and Oligo-Miocene, driven by the collision of Arabia and India with Asia, squeezed and rejuvenated diapirs between laterally mobile suprasalt minibasins (Volozh et al., 2003a; Duffy et al., 2017; Fernandez et al., 2017). This important albeit relatively mild shortening event, is recorded by: (i) folding of the relatively thick (>500 m) roofs of the diapirs, indicating rejuvenation and active diapirism at this time (Figs $2 \mathrm{~B}$ and 5); (ii) the formation of secondary welds between suprasalt minibasins; and (iii) inter-minibasin thrusting (see also Duffy et al., 2017 for a full discussion). As discussed by Duffy et al. (2017), where encased minibasins were absent, the suprasalt minibasins were put into direct contact along sub-vertical secondary welds. In contrast, where encased minibasins were present, they kept apart the suprasalt minibasins and stopped them from welding . As a result, post-subsidence shortening means that some suprasalt minibasins are closer together than when they formed, and their spatial relationship to the encased minibasins has been modified. 
We use two time-migrated 3D seismic reflection datasets that together cover $2532 \mathrm{~km}^{2}$ of the eastern Precaspian Basin, onshore Kazakhstan; these surveys have been merged to produce one interpretable volume. The $2010\left(1252 \mathrm{~km}^{2}\right)$ and $2011\left(1280 \mathrm{~km}^{2}\right)$ surveys both image to 6 seconds two-way time (s TWT) and have a vertical sample rate of 2 milliseconds (ms). Inline (E-W) and crossline (N-S) spacing is $20 \mathrm{~m}$. The seismic data are presented with Society of Economic Geologists (SEG) 'normal polarity', where a downward increase in acoustic impedance is represented by a positive reflection event (white on seismic sections) and a downward decrease in acoustic impedance is represented by a negative reflection event (black on seismic sections). Our time-migrated dataset has better stratigraphic imaging of suprasalt minibasins than the depth-migrated volume used by Duffy et al. (2017) and Fernandez et al. (2017) in their analysis of the more deeply buried encased minibasins (Figs 4 and 5). We therefore use the time-migrated dataset for our detailed analysis of the suprasalt minibasins. However, because of their better imaging of deep structures, we here use two images from these depth-migrated seismic data; (i) a top-allochthonous-salt depth map (Fig. 4A); and (ii) a top-encased-minibasins depth map (Fig. 4B) (see Duffy et al., 2017 and Fernandez et al., 2017).

Numerous boreholes lie within the area covered by the seismic reflection dataset, although most are relatively shallow, terminating in Upper Triassic strata. The two boreholes penetrating older (i.e. Late Permian) strata contained in encased basins (KN-501 and KN-E-201-205) penetrate areas of thick salt and do not intersect intervening suprasalt basins; because of this, the age of the stratigraphy within the suprasalt minibasins is thus poorly constrained (Fernandez et al., 2017). However, given the Kungurian to Kazanian (Permian) age of the salt, and the stratigraphic position of the base Jurassic Unconformity, encased and suprasalt basins are likely Late Permian to Triassic (Figs 3 and 5). The lack of borehole data mean we utilize seismic-stratigraphic relationships to define genetic packages we believe document discrete phases of minibasin subsidence (see below).

We also use physical sandbox models to explore which mechanisms control the subsidence patterns documented in natural minibasins mapped in the Precaspian Basin and elsewhere. These models allow us to systematically investigate how changes in salt thickness, related to base-salt relief, might impact impact minibasin subsidence patterns (cf. Callot et al., 2016). Details on the model materials and set-up are provided below and in the related figure captions.

\section{EVIDENCE FOR COMPLEX MINIBASIN TILTING}

\section{Description}

The salt structures (and their encased minibasins) flank 22 suprasalt minibasins that are up to $10 \mathrm{~km}$ in 
minibasins are typically welded to presalt strata (primary welds) or, in several cases, against or atop encased minibasins (tertiary welds) (Fig. 5) (see also Duffy et al., 2017). Reflections within the suprasalt minibasins show highly variable dips (see below), but invariably onlap onto and are upturned against flanking diapirs (Fig. 5).

In the absence of boreholes directly constraining the age of the stratigraphic infill of suprasalt minibasins, we use reflection terminations (e.g. onlap, erosional truncations) to define geometrically distinct seismic sequences (e.g. bowls, wedges, layers; Fig. 1A-C). It should be noted however that, because of their unique subsidence and sedimentation histories, the number of reflections mapped within each minibasin varies and it is not therefore possible to confidently correlate seismic sequences between them. These issues notwithstanding, we identify and map a range of seismic-stratigraphic architectures that document the unique subsidence histories of individual minibasins. In the following sections we provide detailed descriptions of the seismic-stratigraphic architecture of three of the 22 minibasins, 16 of which are fully imaged by the seismic reflection dataset (minibasins 7,9 and 18; Figs 4C). These three minibasins are very well-imaged, and capture the full range of seismic-stratigraphic architectures and subsidence patterns identified within the other 13, fully imaged suprasalt minibasins.

\section{Minibasin 9 - Vertical symmetrical subsidence superseded by unidirectional asymmetrical subsidence}

Minibasin 9 is located in the north-central part of the seismic dataset (Fig. 4C). Minibasin 9 is not directly underlain by encased basins, although a relatively large encased minibasin lies c. $5 \mathrm{~km}$ to the south-southwest (labelled ' $U$ ' in Fig. 4C). We identify five seismic-stratigraphic packages in Minibasin 9 (Fig. 6), arranged into three units:

Unit 1. Units 1 is directly underlain by top allochthonous salt or its equivalent weld, and is up to $1400 \mathrm{~ms}$ (TWT) thick (true stratigraphic thickness). Unit 1 comprises several bowl-shaped packages (cf. Fig. 1A) that thin towards and onlap onto flanking diapirs , something we note in even the very deepest and thus oldest reflections (Fig. 6A and B). Reflections within Unit 1 dip eastward .

Unit 2. Unit 2 is up to $200 \mathrm{~ms}$ (TWT) thick and comprises a series of wedge-shaped packages (Fig. 6A and C-E; cf. Fig. 1A) that display subtly different thickness patterns (Units 2A-C; Fig. 6A). The lowermost unit thickens east-northeastwards, pinching out west-southwestwards onto the upturned, east-dipping western margin of the underlying bowl-shaped package of Unit 1 (Unit 2A; Fig. 6A and C). In contrast, the middle package dips and thickens eastwards, thus its locus of deposition is offset (c. $1.6 \mathrm{~km}$ ) slightly south-eastwards from that defined in 2A (Unit 2B; Fig. 6A and D). Finally, the depositional locus of the uppermost package is offset a further c. $2 \mathrm{~km}$ east-southeastwards of that defined in Unit 2B, being located immediately adjacent to the salt-sediment interface (Unit 2C; Fig. 6A and $\mathrm{E}$ ). The upper part of Unit $2 \mathrm{C}$, which is more tabular than the wedge-shaped lower part, partly caps, 
and is strongly upturned against the diapir bounding the eastern flank of minibasin 9. The upper part of

260 Unit 2C is thus geometrically similar to Unit 3A (see below) (Fig. 6A). Overall, wedge-shaped packages in minibasin 9 thicken towards encased minibasin U (Fig. 4C).

Unit 3. Unit 3 is up to $400 \mathrm{~ms}$ (TWT) thick and is composed of broadly tabular packages of reflections that are upturned against and may slightly thin towards the steep-dipping flank of the diapir bounding the minibasins eastern margin, and which are erosionally truncated at the present land surface (Fig. 6A). Note that due to post-depositional deformation and arching above the flanking diapirs, and associated erosional truncation of their upper surfaces, these tabular packages have a broadly wedgeshaped form . Basal reflections in Unit 3 are parallel to those in the upper part of Unit 3, the significance of which we discuss further below (Fig. 6A).

\section{Minibasin 7 - Vertical subsidence superseded by bi-directional asymmetric subsidence}

Minibasin 7 is located near the western margin of the seismic dataset, and is bound on its eastern and southern flanks by encased minibasins (labelled ' $\mathrm{V}$ ' and ' $\mathrm{W}$ ' in Figs $4 \mathrm{C}$ and 7A). We identify six seismic-stratigraphic packages in Minibasin 7, arranged into three units:

Unit 1. Unit 1 directly overlies allochthonous salt or its equivalent weld, and is up to $830 \mathrm{~ms}$ (TWT) thick (true stratigraphic thickness; i.e. orthogonal to the unit top and base) (Fig. 7A). Unit 1 comprises bowl-shaped packages that thin towards and onlap onto the flanking diapirs even in the very deepest and thus oldest stratigraphic intervals (cf. minibasin 9; Fig. 6A). Reflections within Unit 1 presently dip eastward (Fig. 7A and B).

Unit 2. Unit 2 is up to $2000 \mathrm{~ms}$ (TWT) thick (Fig. 7A) and comprises three wedge-shaped packages (Fig. 7C-E ). A key observation we make is that, although geometrically similar, wedgeshaped packages in Unit 2 vary dramatically in their direction of thickening and present dip. The and middle (Unit 2B; Fig. 7D) packages thicken north-westwards and northwards, respectively, away from encased minibasins $\mathrm{V}$ and $\mathrm{W}$ (Fig. 4C), despite their internal reflections presently dipping east-southeastwards (Fig. 7A) . contrast, the uppermost package in Unit 2 thickens south-east wards, towards encased minibasin $\mathrm{V}$ and $\mathrm{W}$ (Fig. 4C), with internal reflections having the same dip (Unit 2C ; Fig. 7A and E ).

Unit 3. Unit 3 is up to $1250 \mathrm{~ms}$ (TWT) thick and is split into two sub-units. The lower sub-unit comprises broadly tabular packages of reflections that dip south-eastwards, and which are truncated below the base Jurassic unconformity (Unit 3A; Fig. 7A and F). Units within Unit 3A thin 
towards, are upturned against, and partly overstep the crest of the diapir bounding the western flank of minibasin 7 (Fig. 7A). The upper sub-unit overlies the base Jurassic unconformity and caps all flanking diapirs (Unit 3B; Fig. 7A). Unit 3B is arched above the crest of the diapir bounding the western flank of minibasin 7, recording Late Cretaceous and Oligo-Miocene shortening (Fig. 7A) (Duffy et al., 2017).

Minibasin 18 - Vertical subsidence in adjoining basins superseded by asymmetric subsidence and abrupt shifts in depocentre

Minibasin 18 is located in the south-eastern part of the seismic dataset, where a cluster of three encased minibasins bound its south-western flank (labelled ' $\mathrm{X}$ ', ' $\mathrm{Y}$ ' and ' $\mathrm{Z}$ '; Figs 4C and 8A). We identify five seismic-stratigraphic packages in Unit 18, which we group into three units:

Unit 1. Unit 1 directly overlies allochthonous salt or presalt strata across a primary weld, and is up to $520 \mathrm{~ms}$ (TWT) thick (true stratigraphic thickness). Unit 1 is internally defined by two bowl-shaped packages that thin towards and onlap onto flanking diapirs, and which are partly separated by a lowrelief, slightly NW-elongate diapir ('IMB' in Fig. 8A and B). Although seismic imaging at the base of minibasin 18 is poorer than in minibasins 9 and 7, we still note stratigraphic onlap onto salt in the deepest and thus oldest reflections (Fig. 8A; cf. Figs 6A and 7A). Reflections within Unit 1 presently dip northwards (Fig. 8B).

Unit 2. Unit 2 is up to $2000 \mathrm{~ms}$ (TWT) thick and comprises two main wedge-shaped packages. As we observed in minibasin 7, wedge-shaped packages in minibasin 18 display strikingly different thickness patterns despite being geometrically similar. The lowermost package thickens north-eastward, away from encased minibasins X, Y, and Z (Fig. 4C), although internal reflections presently dip westsouthwestwards (Unit 2A; Fig. 8A and C). In contrast, Unit 2B thickens northward, with internal reflections presently dipping west-southwestwards, towards underlying uncased minibasins (Unit 2B; Fig. 8A and D; see also Fig. 4C).

Unit 3. Unit 3 is up to 1500 ms (TWT) thick and is composed of broadly tabular packages of reflections. As in minibasin 7, we define two sub-units in Unit 3. The lower sub-unit dips southwestwards and is truncated below the base Jurassic unconformity towards the north-northeast. Along the south-western edge of the minibasin, the lower part of Unit 3 thins towards, onlaps onto, and is upturned against the folded upper surface of Unit 2; in contrast, the upper part of Unit 3 is more tabular , capping the flanking diapir (Unit 3A; Fig. 8A). Unit 3B overlies the base Jurassic Unconformity, is more gently dipping than $3 \mathrm{~A}$, and is truncated at the present land surface 
(Fig. 8A). Unit 3B extends across and is arched above the diapir bounding the western half of minibasin 18 (Fig. 8A).

\section{Interpretation}

The lower parts of all three minibasins are clearly composed of bowl-shaped rather than tabular packages. These packages progressively thin towards and onlap onto flanking diapirs (Unit 1). We follow Rowan and Weimer (1998) and interpret this seismic sequence architecture records an initial phase of relatively simple symmetric subsidence of the minibasins into underlying salt (see also Hudec et al., 2009, Kergaravat et al., 2017, and Teixell et al., 2017; see Fig. 1A-C). In the case of minibasin 18, initial subsidence was characterized by the formation of two bowl-shaped minibasins separated by a small diapir; these two minibasins eventually coalesced by the end of Unit 1 to form a single minibasin (Fig. 8A and B). In all cases, the fact that the very lowermost strata onlap flanking diapirs suggests the minibasins began to subside relatively early and when they were very thin (i.e. at a time when they were not sufficiently thick or dense to sink under their own weight into underlying salt; see discussion by Hudec et al., 2009 and Rowan, 2019). Similar, seemingly anomalously early subsidence occurred in minibasins exposed in the Sivas Basin, Turkey (Kergaravat et al., 2017) and in the Moroccan High Atlas (Teixell et al., 2017), and has been invoked for the encased minibasins encountered in the Precaspian Basin (Fernandez et al., 2017). Using borehole data, Fernandez et al. (2017) argue that the encased minibasins subsided early because their basal parts contain evaporitic rocks denser than underlying halite (e.g. gypsum and anhydrite). This served to dramatically reduce the minibasin thickness required to achieve a buoyancy inversion. We suggest this model can be applied to suprasalt as well as the encased minibasins, with the former also likely containing substantial quantities of dense anhydrite (Barde et al., 2002b).

The middle and upper parts of minibasins 7, 9 and 18 comprise dominantly wedge- (Unit 2) rather than bowl-shaped seismic sequences, thus recording a phase of asymmetrical subsidence and minibasin tilting (cf. Rowan and Weimer, 1998; Hudec et al., 2009; Kergaravat et al., 2017; Teixell et al., 2017). Shifts in the locus of maximum thickness of wedge-shaped packages within minibasins indicate the direction of minibasin tilting varied through time. In the case of minibasin 9, this subsidence variability was quite subtle, with broadly east-northeastward tilting (i.e. Unit 2A; Fig. 6C) being superseded by eastward tilting (Units $2 \mathrm{~B}$ and $\mathrm{C}$; Fig. 6D and E). In contrast, more extreme variability in subsidence locus is documented in Minibasin 7, which initially tilted northwestwards (i.e. Unit 2A; Fig. 7C), then north-northwestward (Unit 2B; Fig. 7D), and eventually south-eastward (Unit 2C ; Fig. 7E). Minibasin 18 displays similarly complex variations in subsidence, initially tilting north-eastwards (Fig. 8C) and then northwards (Fig. 8D), before being tilted towards westwards (Fig. 8E). Truncation of the wedge-shaped unit 2B and more tabular Unit 3A below the base Jurassic Unconformity suggest this last phase of basin deformation reflects late-stage shortening and bulk 
westwards tilting of minibasin 18 around a sub-horizontal axis. Such geometries could record deposition of growth strata in the hangingwalls of salt-detached normal faults during thin-skinned extension (e.g. Lundin, 1992; Mauduit \& Brun, 1998; Quirk \& Pilcher, 2012). However, we reject this interpretation for the following three reasons: (i) in most cases, unlike that shown in Quirk and Pilcher (2012), salt contact-related normal faults are either absent (e.g. Fig. 6A), dip in towards the minibasin, but are positioned some distance inboard of the salt crest flank (e.g. Figs 5 and 7A), and/or occur near the salt crest flank, but dip away from the minibasin (e.g. Fig. Fig. 8A); (ii) the direction of wedge thickening, and the locus of minibasin subsidence, varies migrates through time, sometimes in a rather abrupt manner; this implies that the active portion of the causal normal fault also migrated in a somewhat random fashion around the salt-sediment interface. We do not deem this plausible, not least because it would suggest multidirectional extensional spreading across the entire minibasin array (Fig. 9); and (iii) this style of salt-related deformation ('flip-flop salt-tectonics' of Quirk \& Pilcher, 2012) is more likely to result in the formation of relatively straight, strike-elongate faults that bound elongate minibasin depocentres, rather than strongly curved faults bounding ovate depocentres (Fig. 4A). Instead, we argue these geometries simply represent minibasin subsidence and tilting during purely passive diapirism; we explore the origins of the tilting further below.

The upper parts of all three minibasins are defined by sequences that display less pronounced thickness changes than observed in units 1 and 2 (Unit 3; Figs 6-8). Based on geometrical differences, we defined two sub-units in Unit 3. The lowermost sub-unit, Unit 3A: (i) conformably overlies and has a similar dip to relatively steeply-dipping, wedge-shaped sequences defining Unit 2; (ii) very locally thins, onlaps onto, and is upturned against flanking diapirs, at least in its lowermost part; (iii) contains almost perfectly sub-horizontal reflections that persist for several kilometres away from the flanking diapirs, before being eroded below the base Jurassic Unconformity; and (iv) dips more steeply than and is thus truncated at its top by the base Jurassic Unconformity. Based on these geometrical characteristics, we suggest Unit 3A was deposited during the final stages of minibasin subsidence and diapir rise, immediately prior to welding, and just before the onset of the major pre-Jurassic regional shortening event that caused diapir squeezing and minibasin tilting (Duffy et al., 2017). Shortening means wedge-shaped packages in Unit 2 now thicken in the opposite direction to the present structural dip (i.e. Figs 7A and 8A), or dip in a different direction to that which characterized the subsidence regime at the time of their deposition. Unit $3 \mathrm{~A}$ was tilted along with underlying minibasin strata, being erosionally truncated below the base Jurassic Unconformity.

The uppermost sub-unit, Unit 3B, is also internally composed of sub-horizontal reflections, but differs to Unit $3 \mathrm{~A}$ in that it is: (i) more gently-dipping than underlying unit $3 \mathrm{~A}$ and 2 , unconformably overlying them across the base Jurassic Unconformity; and (ii) does not onlap flanking diapirs, but instead caps and is arched above them. Based on these observations we interpret Unit 3B records sediment aggradation after minibasin welding (cf. Fig. 1A). Accommodation at this time was provided 
by long-wavelength, regional basin subsidence. Subsequently, Early Cretaceous regional shortening has further squeezed the diapirs and arched their tabular roofs (Figs 5-8) (Duffy et al., 2017).

\section{ARRAY-SCALE SUBSIDENCE VARIABILITY}

Inspired by the subsidence variability observed in minibasins 7,9 , and 18 , we undertook a detailed seismic-stratigraphic analysis of the other 13 minibasins fully imaged within the 3D seismic volume (note that six of the 22 minibasins lie at the edge of the seismic dataset and are thus not fully imaged; Fig. 9). Our results show that most minibasins contain bowl-shaped packages at their base, indicating most commenced with a phase of broadly symmetrical subsidence (Fig. 10). This phase was typically followed by several phases of asymmetric subsidence, a pattern observed in several exposed minibasins (e.g. Kergavarat et al., 2017; Teixell et al., 2017), and one that is broadly consistent with models relating the bowl-to-wedge transition to salt welding (Fig. 1A; see also the natural example in Fig. 1C) (Rowan \& Weimer, 1998). However, we note that the switch to asymmetric subsidence seemingly occurs at different stages in different minibasins. For example, in some minibasins this switch occurred relatively early (i.e. after only c. $25 \%$ of the total minibasin-fill) in their histories (e.g. minibasins 3, 7, 10, 17 and 18; Fig. 10). In contrast, in other minibasins this switch occurred significantly later (e.g. minibasins 4-6, 12-14 and 16), or not at all (e.g. Minibasin 1 is dominated by symmetric subsidence throughout its history; Fig. 10). Additional notable exceptions to the general pattern described above occur in minibasins 2 and 15, where bowl-shaped packages overlie wedge-shaped packages, rather than vice-versa (Fig. 10). The reason for this is unclear, although we discuss possible mechanisms below.

In addition to the relative timing of the transition in subsidence style seemingly varying between minibasins, the direction of tilting during the asymmetrical subsidence phase was also highly variable. For example, having undergone an initial phase of symmetric subsidence, some minibasins then underwent unidirectional tilting (e.g. minibasins 3, 8, 9 and 12; Fig. 9). In contrast, others minibasins had more complex histories, being defined by either broadly a clockwise (e.g. minibasins 7 and 10) or anticlockwise (e.g. minibasins 7 and 10) rotation of the direction of tilting, or seemingly random jumps in the direction of tilting (e.g. minibasins 1, 2, 13, 15, 18 (Fig. 9). A key observation is that there is a very poor relationship, across the study area, between the direction of minibasin tilting and the presence of an underlying, encased minibasin; i.e. suprasalt minibasins do not consistent tilt away from encased minibasins into areas of thicker salt.

\section{DISCUSSION}

What are the key seismic sequence architectures occurring in minibasins? 
443 'Bowls', 'wedges' and 'layers' (sensu Rowan \& Weimer, 1998) are the main seismic-stratigraphic 444 geometries mapped in seismically-imaged minibasins in the Precaspian Basin, onshore Kazakhstan. We follow Rowan and Weimer (1998) by inferring that bowls and wedges record symmetric and asymmetric subsidence, respectively, whereas layers document post-welding aggradation of sediment above a minibasin and its flanking diapirs. We show that asymmetric subsidence may be associated with abrupt, relatively large-magnitude changes in the direction of tilting (Figs 7 and 8; see also, for example, minibasin 17 between times ' 3 ' and ' 4 ', and minibasin 8 between times ' 2 ' and ' 3 '; Fig. 9); this, together with post-subsidence shortening and associated tilting of minibasins around a subhorizontal axis, can lead to unusual seismic-stratigraphic geometries. For example, earlier formed wedges may be rotated to such a degree that they now thicken in the opposite direction to the present structural dip (e.g. Unit 2A in Fig. 7A ; units 2A and B in Fig. 8A ). At the most basic level, because of this temporally and spatially complex subsidence history, our study shows that simple $2 \mathrm{D}$ seismic profiles (e.g. Rowan \& Weimer, 1998; Hudec et al., 2009) or cross-sections constructed from outcrop data (e.g. Kergaravat et al., 2017; Teixell et al., 2017) may not capture the true stratal geometries preserved within salt minibasins.

For example, packages appearing tabular and isopachous in one view, and which seemingly document uniform aggradation, may in fact be wedge-shaped and thicken out-of-plane and instead document strongly asymmetric subsidence (e.g. Unit 3 in minibasin 7; Fig. 7A and D). Thickness maps are therefore essential to accurately capture thickness variations in minibasin stratigraphic packages and constrain the style of minibasin subsidence (cf. Clark et al., 1998).

\section{What controls minibasin subsidence patterns?}

Based on when the bowl-to-wedge transitions occurs as a percentage of a minibasins fill, we suggest the switch from symmetrical to asymmetrical subsidence occurred at different times within even closely spaced minibasins. Following the transition to asymmetrical subsidence, and timing uncertainties aside, it is clear that the direction of tilting during the asymmetrical subsidence phase was highly variable. So, what mechanism(s) controlled such temporal and spatial variations in minibasin subsidence in the Precaspian Basin? Answering this question is not straightforward because: (i) Late Cretaceous and Oligo-Miocene regional shortening means the minibasins are now not only closer together than they were immediately post-welding, but also have a different spatial relationship to underlying encased minibasins, which could have impacted how they subsided (see below; see also Duffy et al., 2017; Fernandez et al., 2017). Minibasins may also have rotated around a (sub-)vertical axis during shortening, meaning present-day thickness patterns do not truly capture the true locus of syndepositional subsidence (Rowan \& Vendeville, 2006); and (ii) a lack of biostratigraphic data mean we cannot constrain when individual minibasins began to subside, nor when asymmetric subsidence commenced. These limitations notwithstanding, based on observations from other salt basins and 
physical models (see below), and the regional geological evolution of the Precaspian Basin, we now explore some of the mechanisms that may have controlled subsidence patterns here and in other basins.

First, variations in subsidence style may have been controlled by spatial variations in salt thickness and bulk rheology imposed by the latest Permian encased minibasins, a hypothesis we explore with three physical models (Figs 11-14; see also minibasins (i) and (ii) in Fig. 15). In these models, silicon is used as the salt analogue, whereas the minibasins are composed of sand; the bulk density of the minibasins is $10-20 \%$ greater than that of the underlying silicon, hence subsidence is purely density driven (see Duffy et al., 2019 for details). Model 1 replicates density-driven subsidence of an isolated minibasin into a 'sea' of salt of uniform rheology and thickness (Figs 11A and 12A-B; see also Duffy et al., 2018) and shows this minibasin underwent simple symmetric subsidence throughout much of its history (Fig. 12C). This style of subsidence was recorded by deposition of bowl-shaped stratigraphic packages, with welding indicated by a relatively abrupt upward change to tabular, subhorizontal packages that extend across flanking diapirs (Fig. 12C). Model 2 also replicates purely density-driven subsidence of a minibasin but, in this case, the underlying salt varies in thickness and bulk rheology due to the presence of encased minibasins (Fig. 11B). The minibasin in Model 2 was nucleated above the flank of an encased minibasin, between an area of thick salt (i.e. a diapiric feeder) and thin salt (i.e. in the allochthonous canopy) above the encased minibasin (Figs 11B and 13A). Spatial changes in salt thickness and bulk rheology mean that the subsidence history of the minibasin in Model 2 was more complex than Model 1. Symmetric subsidence characterised only the earliest stage of minibasin downbuilding in Model 2, as recorded by the deposition of only one or possibly two bowlshaped packages that, at present, dip west-south-westwards (Fig. 13B-C). Subsequent subsidence was strongly asymmetric, and characterised by west-southwestwards tilting of the minibasin as it subsided more strongly in the area of thick salt; this phase of downbuilding was recorded by deposition of westsouthwestwards thickening wedge-shaped packages (Fig. 13C). Most critically, tilting occurred before the minibasin welded against the deeper encased minibasins, an interpretation supported by the fact that the combined thickness of bowl-shaped packages $(1 \mathrm{~cm})$ at the base of the minibasin is less than the thickness of the underlying salt $(2 \mathrm{~cm})$ initially capping the encased minibasin (Fig. 13C). The suprasalt minibasin eventually became too wide to subside through the narrow neck of the feeder, eventually welding against the encased minibasins (Fig. 13B-C). The minibasin subsidence patterns documented in Model 2 reflect the fact that the resistive force to salt flow increases as the salt layer thins (Wagner \& Jackson, 2011). As such, the overall salt flow velocity slows as the salt starts to weld, and the minibasins subsidence are 'drawn' towards areas of thicker, more freely flowing, and thus more easily expelled salt (i.e. diapiric feeders). The minibasin eventually weld as they become too large to subside further into the feeder (i.e. bucket weld; Pilcher et al., 2011; Jackson \& Hudec, 2017).

Pre-weld tilting also occurred in Model 3, which explores the effect of a simple, plunging subsalt high, and associated changes in salt thickness, on the subsidence patterns of an array of 
allows us to explore whether the transition from bowl- to wedge-shaped sediment packages records minibasin welding and thus primary salt thickness, in this case related to a relatively rigid, basementcored high (e.g. a fault-bound horst) rather than an encased minibasin (i.e. Model 2; Fig. 13C). At the start of the model, minibasins are located to the right of the base-salt structural high; a (left-to-right) moving end-wall caused the minibasins (and underlying salt) to translate downslope towards this high. Initial subsidence patterns of all three minibasins were symmetric, defining bowl-shaped sediment packages (Fig. 14A). As they deepened and translated laterally,

the minibasins began to tilt to the left, away from the sub-salt high

(Fig. 14B). Tilting likely occurred because it was easier to expel underlying salt towards the left, towards an area of locally thicker salt, than to the right, towards an area of locally thinner salt above the base-salt high. Greater tilting occurred in the northern part of minibasin array where the base-salt relief was higher. We suggest this reflects the fact that salt was originally thinner here, and that the differential flux of salt from beneath the subsiding minibasin thus began earlier and hence drove greater tilting (Fig. 14B; see also Fig. 11C). We also note a southwards increase in the degree of clockwise rotation of the minibasin, which we attribute to the fact that those in the south were able to rotate more prior to welding, due to them sinking into and travelling horizontally within thicker salt. Models 2 and 3 broadly replicate the Late Permian-to-Triassic setting of the Precaspian Basin; i.e. suprasalt minibasins subsided through a salt layer of varying thickness, with these variations caused by encased minibasins (Duffy et al., 2017 and Fernandez et al., 2017). In the case of Model 3, subsiding minibasins may have been translating horizontally in response to synsubsidence shortening (see below) or base-salt tilting. In basins lacking a precursor phase of minibasin formation and encasement, salt thickness variations and complex minibasin subsidence patterns may simply reflect subsalt relief generated by faults or folds (Dooley et al., 2017), or base-salt highs generated by sediments deposited between spreading sheets during canopy formation (Jackson \& Hudec, 2017). Although the deep structure is poorly constrained, such a case may also apply to the Azag n'Oufelloussene minibasin in the Moroccan High Atlas. Here, differential expulsion of salt and asymmetrical subsidence occurred prior to welding, possibly driven by salt thickness variations controlled by subsalt, rift-related relief (Moroccan High Atlas; Teixell et al., 2017; see their fig. 14). In our Precaspian Basin example, late regional shortening, the magnitude of which is poorly constrained within our study area, means the original spatial relationship between encased and suprasalt minibasins has likely been modified (Duffy et al., 2017). This may explain the present lack of a clear spatial relationship between subsidence patterns in the secondary minibasins and the position of encased minibasins (Fig. 9).

Second, lateral differences in the rate of salt expulsion could drive pre-weld tilting and asymmetric subsidence of adjacent minibasins (see minibasins (v) and (vi) in Fig. 15 ). Such variations in salt expulsion could be triggered by the deposition of relatively dense sediments (e.g., anhydrite, carbonate), or local deposition of thicker and thus denser clastic sequence (e.g. by a point-fed depositional system, such as a delta, or a cluster of deep-water channels; cf. 'sedimentary topographic' 
loading of Hudec et al. 2009), along one side of a minibasin. More salt will be expelled from the more rapidly subsiding margin, leading to tilting in that direction prior to welding. A local increase in salt flux from beneath the more rapidly subsiding margin of the minibasin may then trigger tilting of adjacent minibasins away from this location, thus setting up array-scale kinematic interactions (see above and minibasins (v) and (vi) in Fig. 15 ) (Fernandez et al., 2019). This mechanism may be applicable to the Precaspian Basin, given that fluvial clastics and evaporites represent much of the sedimentary fill of the suprasalt (and encased) minibasins (Barde et al. 2002b).

Third, regional shortening can drive minibasin formation, with diapir squeezing and inflation leaving intervening minibasins as bathymetric depressions that can accumulate sediment (Hudec et al., 2009). Subtle differences in the rate of shortening-driven diapir rise may cause minibasin tilting, as minibasins tilt away from more rapidly rising diapirs. Critically, this type of tilting can occur prior to welding (see minibasins (v) and (vi) in Fig. 15 ). For example, early syn-subsidence shortening may have driven pre-weld tilting of minibasins in the Sivas Basin, Turkey (Kergaravat et al., 2017; see their figs $15 \mathrm{~A}-\mathrm{C}$ and $16 \mathrm{~B}$ ), with later shortening-induced variations in the rate of diapir rise triggering even more extreme tilting (their figs 15D-E). A local increase in salt flux from beneath the more rapidly subsiding margin of the minibasin may also trigger tilting of adjacent minibasins (see above and minibasins (v) and (vi) in Fig. 15 ). This model may be applicable to the Precaspian Basin, given Uralian Orogeny-related regional shortening likely occurred during Late Permian-to-Triassic subsidence of the suprasalt minibasins (Sokolova et al., 1973; Barde et al., 2002a; Volozh et al., 2003). However, it must be noted there is no direct evidence minibasin initiation or subsidence was coeval with shortening (e.g. presence of thrusts in the deeper parts of the minibasins; Hudec et al., 2009). This may reflect that fact that related shortening strains were buffered by squeezing of relatively wide diapirs.

Finally, minibasin tilting prior to welding could be driven by syn-subsidence lateral translation of minibasins into a lateral buttress (not shown in Fig. 15 ). In the case of the Precaspian Basin, this buttress would be represented by an encased minibasin. In this context, lateral translation of suprasalt minibasins may have occurred due to syn-subsidence shortening imposed by the Late Permian-toTriassic, Uralian Orogeny (Sokolova et al., 1973; Barde et al., 2002a; Volozh et al., 2003).

This discussion highlights that several mechanisms may cause minibasin tilting occur prior to welding. As a result, the switch from bowl- to wedge-shaped stratigraphic packages may not record weld timing and the original salt thickness. Future work should focus on examples in which the age and composition of stratigraphy within individual minibasins is better-constrained, and where independent evidence for regional tectonic events is available.

What implications do minibasin subsidence patterns have for hydrocarbon exploration in saltbearing sedimentary basins? 
589 Halite, which is the most abundant mineral in many salt formations, has a very low permeability $\left(10^{-20}\right.$ $590 \mathrm{~m}^{2}$; e.g. Jackson and Hudec, 2017). Thus, depending on their composition (see Wagner and Jackson, 591 2011; Jackson et al., 2014) the development of salt welds is often critical to allow transmission of 592 hydrocarbons from subsalt source rocks into suprasalt, minibasin-hosted reservoirs, or between adjacent 593 minibasins (Rowan, 2004; Jackson et al., 2014, 2018). The timing of salt welding is also critical (Rowan, 594 2004); for example, if welding occurs after hydrocarbons have been expelled from the source rock, then 595 these hydrocarbons may be either trapped below the salt or may migrate updip into other parts of the 596 subsalt succession. However, if welding occurs before hydrocarbon expulsion, then these hydrocarbons may be able to migrate into and charge suprasalt reservoirs. Establishing when welding occurs may thus be of critical importance when exploring for hydrocarbons.

Based on their study of 2D seismic and borehole data from the Gulf of Mexico, Rowan and Weimer (1998) suggest that the transition from bowl- to wedge-shaped seismic sequences may indicate the timing of welding. However, our physical models indicate strongly asymmetrical subsidence and minibasin tilting can occur prior to welding, and that they may instead document spatial variations in the rate and amount of evacuation of salt from beneath a descending minibasin (e.g. Fig. 4). Furthermore, we speculate that the transition from bowl- to wedge-shaped seismic sequences in the Precaspian Basin may likewise predate welding. Using the timing of the bowl-to-wedge transition to indicate the timing of welding may thus falsely suggest that welding occurred earlier than it really did. The impact of this on exploration risking is clear; if maturation, expulsion and migration of subsalt source rocks occurs prior to welding, then suprasalt reservoirs may not be charged, even if, at present, minibasins are welded to subsalt strata. It is thus critical to understand what controls minibasin subsidence style in salt-bearing sedimentary basins when risking, in particular, suprasalt prospects relying on charging from subsalt source rocks.

In addition to constraining (or not constraining) the timing of welding and the likelihood of charging suprasalt reservoirs, the style of minibasin subsidence also controls the distribution of clastic

614 reservoirs . For example, submarine (e.g. Prather et al., 1998; Kane et al., 2012) and fluvial (e.g. 615 Hodgson et al., 1992; Matthews et al., 2009; Banham and Mountney, 2013) channels are typically 616 sensitive to syn-depositional relief, typically being drawn towards bathymetric lows (Fig. 1D). Thus, 617 one may anticipate that reservoirs associated with these systems may occur at specific locations within 618 the three seismic-stratigraphic architectures identified in the Precaspian Basin. For example, 619 channelised clastic reservoirs may be preferentially preserved towards the centre of bowl-shaped 620 sequences (e.g. Hodgson et al., 1992; Matthews et al., 2009; Banham and Mountney, 2013), whereas 621 they may be best-developed at the thicker end of wedge-shaped sequences, near the salt-sediment 622 contact (Fig. 1D). In contrast, within isopachous layers deposited during long-wavelength, uniform subsidence, these reservoirs may be more evenly distributed across strike. In association with intraformational stratal thinning, onlap and truncation, reservoirs may pinchout updip into sealing 
lithologies and thus be stratigraphically-trapped towards the thin end of these wedge-shaped packages. Reservoirs in the centres of bowl-shaped seismic sequences may rely on more subtle stratigraphic trapping configurations, or post-depositional structural deformation related to turtle anticline formation (Jackson and Hudec, 2017) or shortening (Mannie et al., 2014). For example, the thickest shallow marine reservoirs in the Ula minibasin (Upper Jurassic), eastern Central Graben, offshore Norway are located at the centre of a broadly bowl-shaped seismic sequence, thinning and onlapping towards the bounding salt-cored structural high (fig. 12 in Mannie et al., 2014). The aforementioned discussion is predicated on the fact that the basin is underfilled and that at-surface relief is developed during minibasin subsidence; e.g. if the minibasin is overfilled, then channel systems may be able to avulse and deposit broader, more sheet-like reservoir elements that are not directly restricted to the location of maximum sediment preservation. In the Precaspian Basin we lack borehole data to test this hypothesis, although it may be testable in other data-rich salt-bearing sedimentary basins (e.g. Gulf of Mexico, North Sea).

\section{CONCLUSIONS}

We use 3D seismic reflection data from the Precaspian Basin, onshore Kazakhstan to define the main seismic-scale sequence architectures developed as minibasins subside into salt of varying thickness. We show that bowl-shaped stratigraphic packages are typically overlain by wedge-shaped packages, with the switch between the two recording a change from symmetric to asymmetric subsidence. A key conclusion is that asymmetric subsidence may not simply reflect minibasin welding, and that the net-thickness of the lowermost, bowl-dominated package may not faithfully record the thickness of the primary salt layer ; these interpretations are consistent with observations from our physical models. The underlying controls on this change in subsidence style remain unclear, although it may reflect lateral variations in salt thickness and bulk rheology, kinematic interactions between adjacent minibasins undergoing non-uniform subsidence at differing rates, and/or syn-subsidence shortening in or without the presence of a lateral buttress. Irrespective of the precise controls on this subsidence variability, the results of our study have important implications for assessing the timing of hydraulic communication between sub-salt, source rock-bearing strata, and suprasalt reservoirs, and for the distribution of suprasalt reservoirs deposited in minibasins.

\section{ACKNOWLEDGEMENTS}

We thank Condor Petroleum and especially Roger Whittaker for permission to use and publish seismic reflection and borehole data from the Precaspian Basin. The manuscript was edited by Stephanie Jones.

660 The project was funded by the Applied Geodynamics Laboratory (AGL) Industrial Associates program, 
companies: Anadarko, BHP Billiton, BP, CGGVeritas, Chevron, Cobalt, ConocoPhillips, Ecopetrol, 663 Ente Nazionale Idrocarburi (Eni), ExxonMobil, Fugro, Global Geophysical, Hess, INEXS, Instituto 664 Mexicano del Petróleo (IMP), ION Geophysical, Maersk, Marathon, Mariner, McMoRan, Murphy, 665 Nexen, Noble, Petrobras, Petróleos Mexicanos (PEMEX), Petroleum Geo-Services (PGS), Repsol, 666 Samson, Saudi Aramco, Shell, Equinor, TGS-NOPEC, Total, WesternGeco, and Woodside 667 (http://www.beg.utexas.edu/indassoc/agl/agl_if.html). The authors received additional support from the Jackson School of Geosciences, The University of Texas at Austin. Schlumberger are also thanked for providing Petrel software to The University of Texas at Austin and Imperial College. Publication authorized by the Director, Bureau of Economic Geology, The University of Texas at Austin.

\section{REFERENCES}

Banham, S.G. \& Mountney, N.P., 2014. Climatic versus halokinetic control on sedimentation in a dryland fluvial succession. Sedimentology, 61, 570-608.

676

Barde, J.P., Gralla, P., Harwijanto, J. \& Marsky, J., 2002a. Exploration at the eastern edge of the Precaspian basin: Impact of data integration on Upper Permian and Triassic prospectivity. AAPG Bulletin, 86, 399-415.

680

Barde, J.P., Chamberlain, P., Galavazi, M., Gralla, P., Harwijanto, J., Marsky, J. \& van den Belt, F., 2002b. Sedimentation during halokinesis: Permo-Triassic reservoirs of the Saigak field, Precaspian basin, Kazakhstan. Petroleum Geoscience, 8, 177-187.

Brunet, M.-F., Volozh, Y.A., Antipov, M.P. \& Lobkovsky, L.I., 1999. The geodynamic evolution of the Precaspian Basin (Kazakhstan) along a north-south section. Tectonophysics, 313, 85-106.

Callot, J.P., Salel, J.F., Letouzey, J., Daniel, J.M. \& Ringenbach, J.C., 2016. Three-dimensional evolution of salt-controlled minibasins: Interactions, folding, and megaflap development. AAPG Bulletin, 100, 1419-1442.

691

692 Clark, J.A., Stewart, S.A. \& Cartwright, J.A., 1998. Evolution of the NW margin of the North Permian Basin, UK North Sea. Journal of the Geological Society, 155, 663-676. 
Dooley, T.D., Duffy, O.B., Hudec, M.R., \& Fernandez, N., 2019. Translation, Tilting and Rotation of Minibasins in Isolated Minibasin Systems. AAPG Search and Discovery Article, 11229, http://www.searchanddiscovery.com/pdfz/documents/2019/11229dooley/ndx_dooley.pdf.html

Duffy, O.B., Fernandez, N., Hudec, M.R., Jackson, M.P.A., Burg, G., Dooley, T.P. \& Jackson, C.A.L., 2017. Lateral mobility of minibasins during shortening: Insights from the SE Precaspian Basin, Kazakhstan. Journal of Structural Geology, 97, 257-276.

Duffy, O.B., Dooley, T.P., Hudec, M.R., Jackson, M.P., Fernandez, N., Jackson, C.A-L. \& Soto, J.I., 2018. Structural evolution of salt-influenced fold-and-thrust belts: A synthesis and new insights from basins containing isolated salt diapirs. Journal of Structural Geology, 114, 206-221.

Fernandez, N., Duffy, O.B., Hudec, M.R., Jackson, M.P.A., Burg, G., Jackson, C.A.L. \& Dooley, T.P., 2017. The origin of salt-encased sediment packages: Observations from the SE Precaspian Basin (Kazakhstan). Journal of Structural Geology, 97, 237-256.

Fernandez, N., Hudec, M.R., Jackson, C.A.L., Dooley, T.P. \& Duffy, O.B., 2019. The competition for salt and kinematic interactions between minibasins during density-driven subsidence: observations from numerical models. Petroleum Geoscience. EarthArXiv preprint: https://eartharxiv.org/jak5u/.

Ge, H., Jackson, M.P.A \& Vendeville, B.C., 1997. Kinematics and dynamics of salt tectonics driven by

González-Muñoz, J.M., Martín Bañón, J.J. \& Carballo-García, J.A., 2001. Salt tectonics and synsedimentary analysis in the southeastern border of the Pre-Caspian basin (Kazakhstan). Exploratory evaluation of potential traps in Permo-Triassic materials. Bol. Inf. Pet., 68 (2001), pp. 84-96

Gralla, P. \& Marsky, J., 2000. Seismic reveals new eastern Precaspian target. Oil \& Gas Journal, 98, 4.

Hodgson, N.A., Farnsworth, J. \& Fraser, A.J., 1992. Salt-related tectonics, sedimentation and hydrocarbon plays in the Central Graben, North Sea, UKCS. Geological Society, London, Special Publications, 67, 31-63. 
Hudec, M.R., Jackson, M.P.A. \& Schultz-Ela, D.D., 2009. The paradox of minibasin subsidence into salt: Clues to the evolution of crustal basins. Geological Society of America Bulletin, 121, 201-221.

Ismail-Zadeh, A., Wilhelm, H. \& Volozh, Y., 2008. Geothermal evolution of the Astrakhan arch region of the Pricaspian basin. Int. J. Earth Sci., 97, 1029-1043.

Jackson, M.P.A. \& Cramez, C., 1989. Seismic recognition of salt welds in salt tectonic regimes. Proceedings of the GCSSEPM Foundation $10^{\text {th }}$ Annual Bob F. Perkins Research Conference, 66-71.

Jackson, M.P. and Hudec, M.R., 2017. Salt Tectonics: Principles and Practice. 408 Cambridge University409 Press.

Jackson, M.P.A. \& Talbot, C.J., 1991. A glossary of salt tectonics. University of Texas at Austin, Bureau of Economic Geology Geologic Circular, 91, 44 p.

Jackson, C.A.L., Jackson, M.P.A. \& Hudec, M.R., 2015. Understanding the kinematics of salt-bearing passive margins: A critical test of competing hypotheses for the origin of the Albian Gap, Santos Basin, offshore Brazil. Geological Society of America Bulletin, 127, 1730-1751.

Kane, I.A., McGee, D.T. \& Jobe, Z.R., 2012. Halokinetic effects on submarine channel equilibrium profiles and implications for facies architecture: conceptual model illustrated with a case study from Magnolia Field, Gulf of Mexico. Geological Society, London, Special Publications, 363, 289-302.

Lundin, E.R. 1992. Thin-skinned extensional tectonics on a salt detachment, northern Kwanza Basin, Angola. Marine and Petroleum Geology, 9, 405-411.

Kergaravat, C., Ribes, C., Callot, J.P. \& Ringenbach, J.C., 2017. Tectono-stratigraphic evolution of salt-controlled minibasins in a fold and thrust belt, the Oligo-Miocene central Sivas Basin. Journal of Structural Geology, 102, 75-97.

Mannie, A.S., Jackson, C.A-L. \& Hampson, G.J., 2014. Shallow-marine reservoir development in extensional diapir-collapse minibasins: An integrated subsurface case study from the Upper Jurassic of the Cod terrace, Norwegian North Sea. AAPG Bulletin, 98, 2019-2055.

Mauduit, T., \& Brun, J.P. 1998. Growth fault/rollover systems: birth, growth, and decay. Journal of Geophysical Research: Solid Earth, 103, 18119-18136. 
Natal'in, B.A. \& Şengör, A.C., 2005. Late Palaeozoic to Triassic evolution of the Turan and Scythian platforms: the pre-history of the Palaeo-Tethyan closure. Tectonophysics, 404,.175-202.

Pilcher, R.S., Kilsdonk, B. \& Trude, J., 2011. Primary basins and their boundaries in the deep-water northern Gulf of Mexico: Origin, trap types, and petroleum system implications. AAPG Bulletin, 95, 219-240.

Prather, B.E., 2000. Calibration and visualization of depositional process models for above-grade slopes: a case study from the Gulf of Mexico. Marine and Petroleum Geology, 17, 619-638.

Prather, B.E., Booth, J.R., Steffens, G.S. \& Craig, P.A., 1998. Classification, lithologic calibration, and stratigraphic succession of seismic facies of intraslope basins, deep-water Gulf of Mexico. AAPG Bulletin, 82, 701-728.

Quirk, D.G. \& Pilcher, R.S. 2012. Flip-flop salt tectonics. Geological Society, London, Special Publications, 363, 245-264.

Rowan, M.G., 2004. Do salt welds seal? Proceedings of the GCSSEPM Foundation 24th Annual Bob F. Perkins Research Conference (Salt-Sediment Interactions and Hydrocarbon Prospectivity: Concepts, Applications, and Case Studies for the 21st Century), 390-403.

Rowan, M.G., 2019. Conundrums in loading-driven salt movement. Journal of Structural Geology, 125, 256-261.

Rowan, M.G. \& Weimer, P., 1998. Salt-sediment interaction, northern Green Canyon and Ewing bank (offshore Louisiana), northern Gulf of Mexico. AAPG Bulletin, 82,1055-1082.

Rowan, M.G. \& Vendeville, B.C. 2006. Foldbelts with early salt withdrawal and diapirism: Physical model and examples from the northern Gulf of Mexico and the Flinders Ranges, Australia. Marine and Petroleum Geology, 23, 871-891. Boundary, 2, 158-167. 
Teixell, A., Barnolas, A., Rosales, I. \& Arboleya, M.L., 2017. Structural and facies architecture of a diapir-related carbonate minibasin (lower and middle Jurassic, High Atlas, Morocco). Marine and Petroleum Geology, 81, 334-360.

Matthews, W.J., Hampson, G.J., Trudgill, B.D. \& Underhill, J.R., 2007. Controls on fluviolacustrine reservoir distribution and architecture in passive salt-diapir provinces: Insights from outcrop analogs. AAPG Bulletin, 91, 1367-1403.

Volozh, Y., Talbot, C. \& Ismail-Zadeh, A., 2003a. Salt structures and hydrocarbons in the Pricaspian basin. AAPG Bulletin, 87, 313-334.

Volozh, Y.A., Antipov, M., Brunet, M-F., Garagash, I., Lobkovskii, L. \& Cadet, J.P., 2003b, PreMesozoic geodynamics of the Precaspian basin (Kazakhstan). Sedimentary Geology, 156, 35-58.

Worrall, D.M. \& Snelson, S., 1989. Evolution of the northern Gulf of Mexico, with emphasis on Cenozoic growth faulting and the role of salt. In: The Geology of North America-an overview (Eds. in Bally, A.W. \& Palmer, A.R). Boulder, Colorado, Geological Society of America, v. A, 97-138.

\section{FIGURE CAPTIONS}

Fig. 1. (A) Development of bowl (B), wedge (W) and layer (L) stratigraphic/seismic-stratigraphic units during minibasin subsidence and passive diapirism (terminology after Rowan and Weimer, 1998). Note progressive shifts in the axis of subsidence associated with welding and the transition from a primary (stages I and II) to secondary (stages III-IV) peripheral sink (sensu Trusheim, 1960). No scale implied. (B) Depth-migrated seismic section from the Gulf of Mexico showing the seismic-stratigraphic architecture of a Plio-Pleistocene minibasin forming due to subsidence into allochthonous salt. Vertical stacking of bowl-shaped (B) sequences, at least in this two-dimensional profile, documents vertical, broadly symmetrical minibasin subsidence. Modified from Hudec et al. (2009). (C) Geoseismic section (from a time-migrated seismic profile) showing an overall upward transition from bowl- (B) to wedgeshaped (W) seismic sequences in a Plio-Pleistocene minibasins, again subsiding into allochthonous salt in the Gulf of Mexico. Note the abrupt southward shift in depocentre location (between the light-blue and dark-green layers), which is inferred to document the onset of minibasin welding onto subsalt strata. Modified from Rowan and Weimer (1998). (D) Abrupt shifts in minibasin depocentre location due to syn-subsidence shortening. An early bowl-shaped (B) depocentre (light-blue) is almost completely dissected by a post-depositional thrust, which segments the early depocentre into two depocentres (recorded by two bowls (B); green) separated by a thrust-cored high. Asymmetric subsidence (recorded by a wedge-shaped (W) sequence; tan) then occurs due to ongoing shortening, which causes the right- 
hand diapir to inflate more rapidly than the one on the left. Note that this complex seismic sequence architecture occurs prior to welding (cf. Fig. 1A and C). The potential location of deep-water channels is schematically shown, indicating these types of reservoir are likely to occur where syn-depositional subsidence was greatest. Modified from Hudec et al. (2009). (E) Abrupt shifts in depocentre location and strongly asymmetric minibasin subsidence recorded by isopachs, western Platform, North Sea. In this setting, differential subsidence occurred during rather than after salt, likely due to syn-salt deposition of dense anhydrite and carbonate on less dense halite. Modified from Clark et al. (1998).

Fig. 2. (A) Tectonic elements in broader Caspian region, after Natal'in and Şengör (2005). Major orogenic belts=green; Precaspian salt basin=pink; Arabian Plate=orange. Dashed black box outlines area shown in (B). Approximate directions to relevant continental plates and blocks that lie outside of the figure are shown by black arrows. (B ) Salt thickness and structure map of Precaspian Basin. Modified from Volozh et al. (2003a). Regional geographic context is shown in the inset map. Study area is shown by a black box located in the SE corner of the basin. (C ) Broadly ESE-trending cross-section through the SE margin of the Precaspian Basin. The main tectono-stratigraphic and salttectonic features are indicated. The approximate location of the study area is indicated. The approximate location of the cross-section is shown in (B ). Cross-section is from Condor Petroleum's in-house regional study.

Fig. 3. Stratigraphic framework and representative lithologies of key units in the Eastern Precaspian Basin. Modified from Barde et al. (2002b). Key seismic horizons and seismic sequences shown in subsequent figures are indicated (i.e. Figs 5-8). Key tectonic events and phases of inferred salt mobilisation also shown.

Fig. 4. (A) Structure map of top allochthonous salt showing the distribution of key salt-tectonic features within the study area (i.e. diapirs and minibasins; see also Fig. 5). Location of the seismic and geoseismic sections shown in Fig. 5 is indicated. (B) Structure map of top of encased minibasins fully or partly overlain by allochthonous salt (see Fig. 5) (see Duffy et al., 2017 and Fernandez et al., 2017). Stars mark borehole locations. (C) Simplified map compiled from (A) and (B) showing the location of salt diapirs, and encased and suprasalt minibasins. V-Z are encased minibasins referred to in the text, and labelled in Figs 7, 8 and 9 . The locations of maps shown in Figs 6-8 are shown.

Fig. 5. (A) Uninterpreted and (B) interpreted seismic section (from the depth-migrated volume used by Duffy et al., 2017 and Fernandez et al., 2017) showing the main structural elements within the study area. Paired black dots labelled 'p' and 't' are (apparent) （sensu Wagner and Jackson, 2011) primary and tertiary salt welds, respectively. Location of the profile is shown in Fig. 4A. 
880 Fig. 6. (A) E-trending seismic profile across minibasin 9 (for location see Fig. 6B; for location of 881 minibasin see Fig. 4C). Key regional seismic horizons are labelled (BJU=yellow; BCU=orange). White 882 horizons are those locally mapped within this minibasin, where they define boundaries between seismic 883 sequences discussed in the text. The stratigraphic positions of isochrons shown in (B-E) are indicated. 884 Approximate depths scales on the right of the profile are constrained by depth-migrated images presented in Duffy et al. (2017) and Fernandez et al. (2017). (B) Unit 1 isochron. Note that the thin, white, dashed lines show the inferred location of the thickness contours below the overhanging eastern flank of the diapir bounding the western margin of minibasin 9. (C) Unit 2A isochron. (D) Unit $2 B$ isochron. (E) Unit 2C isochron. Numbers in (B) refer to minibasins named in Fig. 4C. Black dots in (B)-(E) indicate depositional maxima and inferred loci of maximum subsidence. Contour interval=50 ms (TWT). The white tick mark in the middle of the minibasin shows the present average strike and dip direction of the surface bounding the top of the displayed isochron.

892

Fig. 7. (A) E-trending seismic profile across minibasin 7 (for location see Fig. 7B; for location of minibasin see Fig. 4C). Key regional seismic horizons are labelled (BJU=yellow; BCU=orange). White horizons are locally mapped within this minibasin, where they define boundaries between seismic sequences discussed in the text. The stratigraphic positions of isochrons shown in (B-E) are indicated. $\mathrm{W}$ is the encased minibasin referred to in the text, and seen in (A) and Fig. 4C. Note that Unit $2 \mathrm{~B}$ is truly wedge-shaped and thickens to the north (see Fig. D); it appears tabular in this profile because this E-trending profile is perpendicular to the direction of wedge-thickening. Approximate depths scales on the right of the profile are constrained by depth-migrated images presented in Duffy et al. (2017) and Fernandez et al. (2017). (B) Unit 1 isochron. (C) Unit 2A isochron. (D) Unit 2B isochron. (E) Unit 2C isochron. (F) Unit 3A isochron. Numbers in (B) refer to minibasins named in Fig. 4C. Black dots in (B)-(F) indicate depositional maxima and inferred loci of maximum subsidence. Contour interval=50 ms (TWT). The white tick mark in the middle of the minibasin shows the present average strike and dip direction of the surface bounding the top of the displayed isochron.

Fig. 8. (A) E-trending seismic profile across minibasin 18 (for location see Fig. 8B; for location of minibasin see Fig. 4C). Key regional seismic horizons are labelled (BJU=yellow; BCU=orange). White horizons are locally mapped within this minibasin, where they define boundaries between seismic sequences discussed in the text. The stratigraphic positions of isochrons shown in (B-E) are indicated. $\mathrm{IMB}=$ intra-minibasin diapir (see text). $\mathrm{X}$ and $\mathrm{Y}$ are the encased minibasins referred to in the text, and seen in (A) and Fig. 4C. Approximate depths scales on the right of the profile are constrained by depthmigrated images presented in Duffy et al. (2017) and Fernandez et al. (2017). (B) Unit 1 isochron. (C)

914 Unit 2A isochron. (D) Unit 2B isochron. (E) Unit 3A isochron. Numbers in (B) refer to minibasins named in Fig. 4C. Black dots in (B)-(E) indicate depositional maxima and inferred loci of maximum 
subsidence. Contour interval=50 ms (TWT). The white tick mark in the middle of the minibasin shows the present average strike and dip direction of the surface bounding the top of the displayed isochron.

Fig. 9. Map showing minibasin subsidence patterns across much of the array shown in Fig. 4A and C. Minibasins 1, 6, 11, 16, 19, 20 and 22 were only partly imaged in our 3D seismic volume and were thus not studied. Numbers show the locations of depocentres defined by seismic sequence thickness mapped in individual minibasins; no temporal linked between seismic sequences between minibasins is implied. Black arrows point in the direction of inferred salt evacuation; this is based on the direction of wedgethickening, which we infer defines the syn-depositional locus of maximum subsidence and hence salt expulsion. V-Z are encased minibasins referred to in the text, and labelled in Figs 4, 7 and 8.

Fig. 10. Chart showing how the distribution of bowl-, wedge-, and layer-shaped seismic-stratigraphic packages vary across the minibasin array, and how their relative thickness vary between minibasins. All minibasins are welded to presalt strata and, in some cases, encased minibasins. Minibasin thickness is calculated from its basal weld to the base Jurassic Unconformity, and is based on true stratigraphic thicknesses to account for severe tilting of earliest deposited strata. The majority of stratigraphic transitions between bowl- and wedge-shaped packages are abrupt, although transitional boundaries are locally observed. For detailed analysis of minibasin 7, 9, and 18 see Figs. 7, 6, and 8, respectively. Maps in Fig. 4B-C indicate the location of encased minibasins as referred to here.

Fig. 11. Initial set-up of physical models. (A) Model 1 (isolated minibasin subsiding in a sea of tabular salt). (B) Model 2 (isolated minibasin subsiding in a salt layer of varying thickness). See text for full discussion. (C) Model 3 (eastward-travelling, isolated minibasins in a sea of salt that changes in thickness along a subsalt high). Note that salt flow and minibasin translation in (C) is initiated by salt flow is then away from the viewer, towards and across the underlying subsalt high (see Fig. 14).

Fig. 12. Results of Model 1. (A) Initial minibasin seed within a sea of tabular salt (see also Fig. 11A). Note that a light dusting of blue sand covers the salt to permit laser-scanning of its top surface. (B)

944 Depth slice through the model, the location of which is shown in (C). Strata are sub-horizontal, except at the minibasin margins where it is upturned against the flanking salt diapir. (C) Cross-sections ( $\mathrm{i}$ and ii) through the model, the locations of which is shown in (B). Note the dominance of bowl- (B) and layer-shaped (L) stratal units below and above, respectively, the horizon marked ' $\mathrm{X}$ '; this stratigraphic transition defines the timing of welding.

Fig. 13. Results of Model 2. (A) Initial (suprasalt) minibasin seed offset from the locus of thick salt within a diapiric feeder (see also Fig. 11B). (B) Depth slice through the model, the location of which is shown in (C). Note the minibasin is almost fully welded, via lateral welds, to the encased minibasins 
953 (see also C). Strata dip west-southwestwards, towards the area of thick salt within the diapiric feeder.

954 (C) Cross-sections (i and ii) through the model, the locations of which is shown in (B). A very thin 955 interval of bowl-shaped packages is only developed at the minibasin base below the horizon marked 956 ' $\mathrm{Y}$ '; above this level, wedge-shaped packages dominate.

957

958 Fig. 14. Results of Model 3 shown as height-change maps of the model top surface. S alt flow and 959 minibasin translation, imposed by a moving end-wall at the left-hand edge of the model, are to the 960 right ,towards the southward-plunging subsalt high. Salt thickness increases and the minibasin:salt 961 thickness ratio decreases (see Fig. 11C for cross-section through model set-up). (A) Early 962 stage of the model run, in which the white dots indicate the locus of minibasin subsidence; and (B) late 963 stage of the model run, in which the white dots indicate the current locus of minibasin subsidence and 964 the red dots the earlier locus of minibasin subsidence. Note the switch from symmetrical to 965 asymmetrical subsidence, with backtilting of the minibasins away from the subsalt high.

966

967 Fig. 15. Sequential (A-D) simplified conceptual diagrams illustrating some of the key controls on 968 minibasin subsidence styles, based on observations from the Precaspian Basin, physical models shown 969 in Figs 11-14 , and other situations in which base-salt relief controls salt thickness (e.g. a subsalt rift). 970 Minibasins nucleate above base-salt highs (i.e. encased minibasins in the case of minibasins (i) and (ii), 971 and a subsalt horst in the case of minibasin (iii)), away from base-salt highs and other minibasins (i.e. 972 minibasin (iv)), or in close proximity to one another, but away from base salt highs (i.e. minibasins (v) 973 and (vi)). Note that minibasin subsidence is simply driven by its excess density and is associated 974 with purely passive diapiric rise; no horizontal shortening is imposed. Horizontal shortening could 975 however enhance differential salt evacuation from below and diapir rise adjacent to minibasins (v) and 976 (vi). Note also that minibasins (iv) and (v) are too far apart to kinematically interact, in contrast to (v) 977 and (vi). Length and thickness of the white arrows show the relative fluxes of salt from beneath a sinking 978 minibasin; pre-welding minibasin tilting can occur where these fluxes are not equal (e.g. minibasin ii 979 in (B), and minibasins v and vi in (C); see Fernandez et al. 2019). See text for full discussion. 
Fig. 1

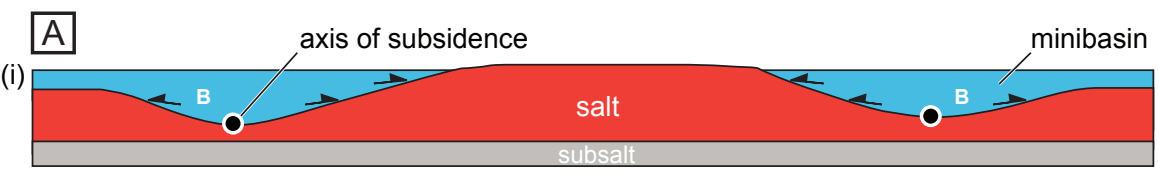

(ii)

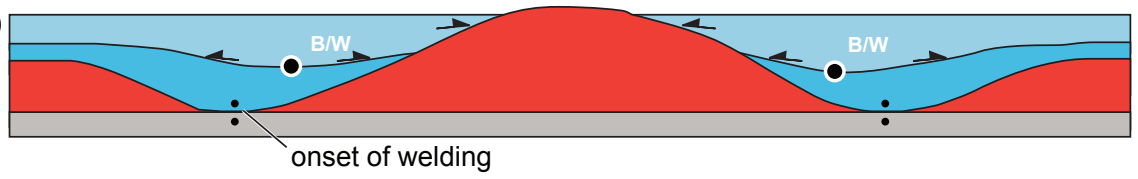

(iii)

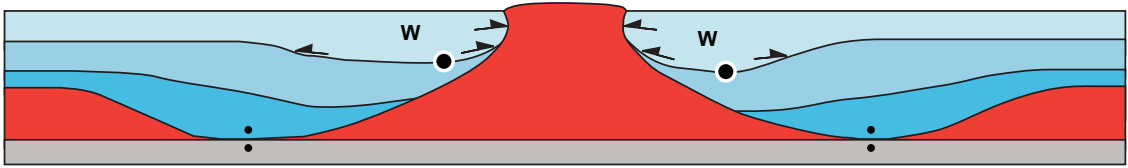

(iv)

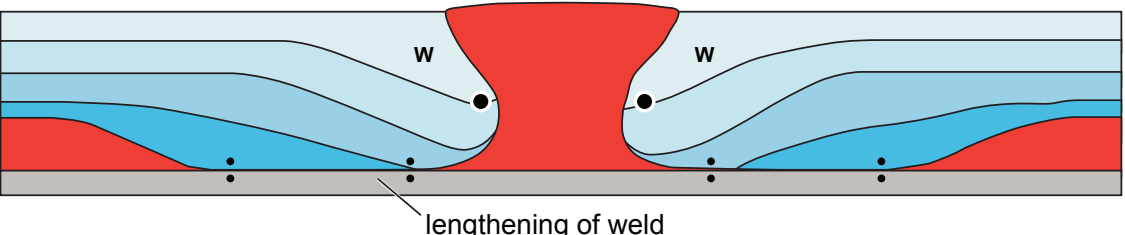

(v)
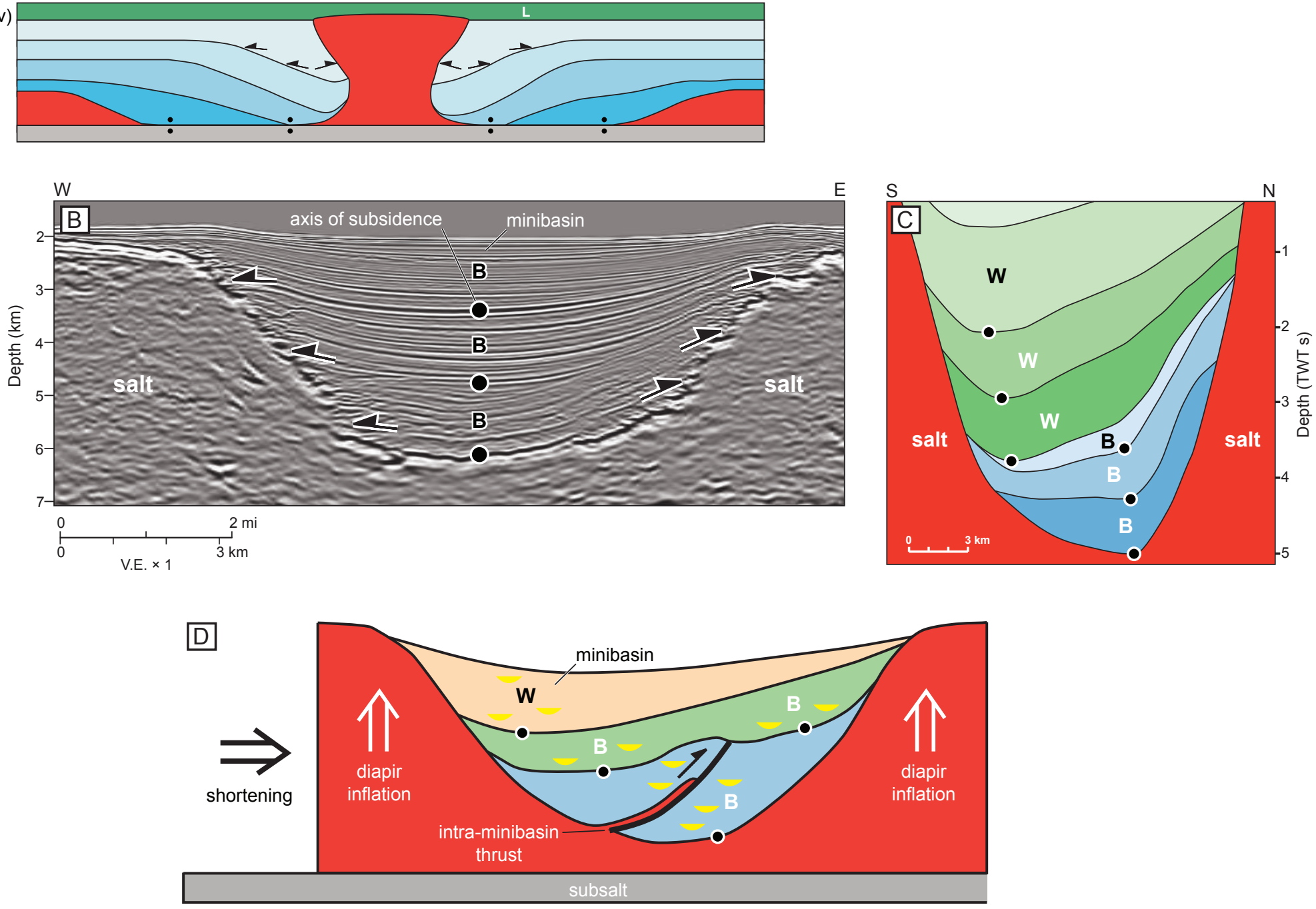
Fig. 1

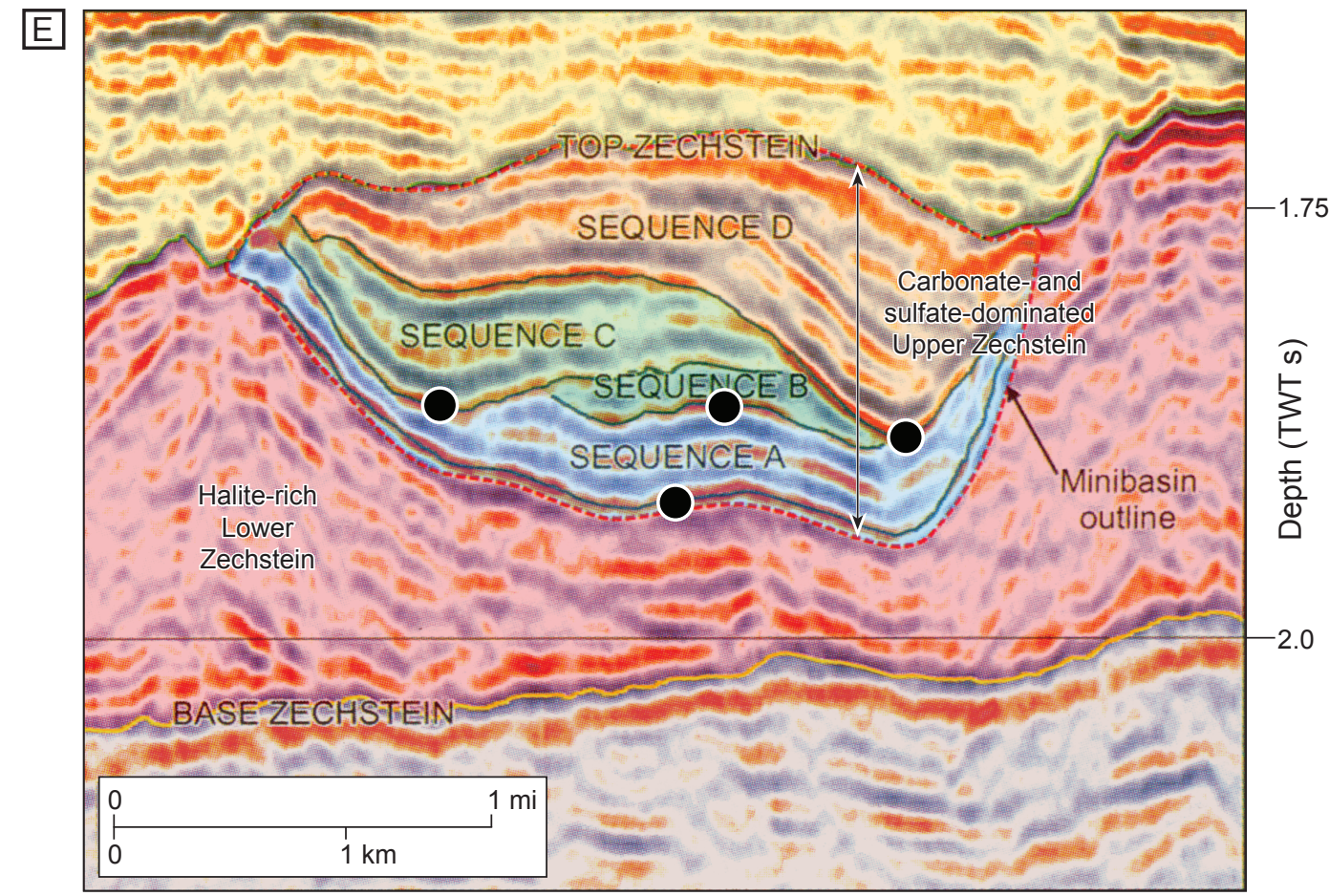

F
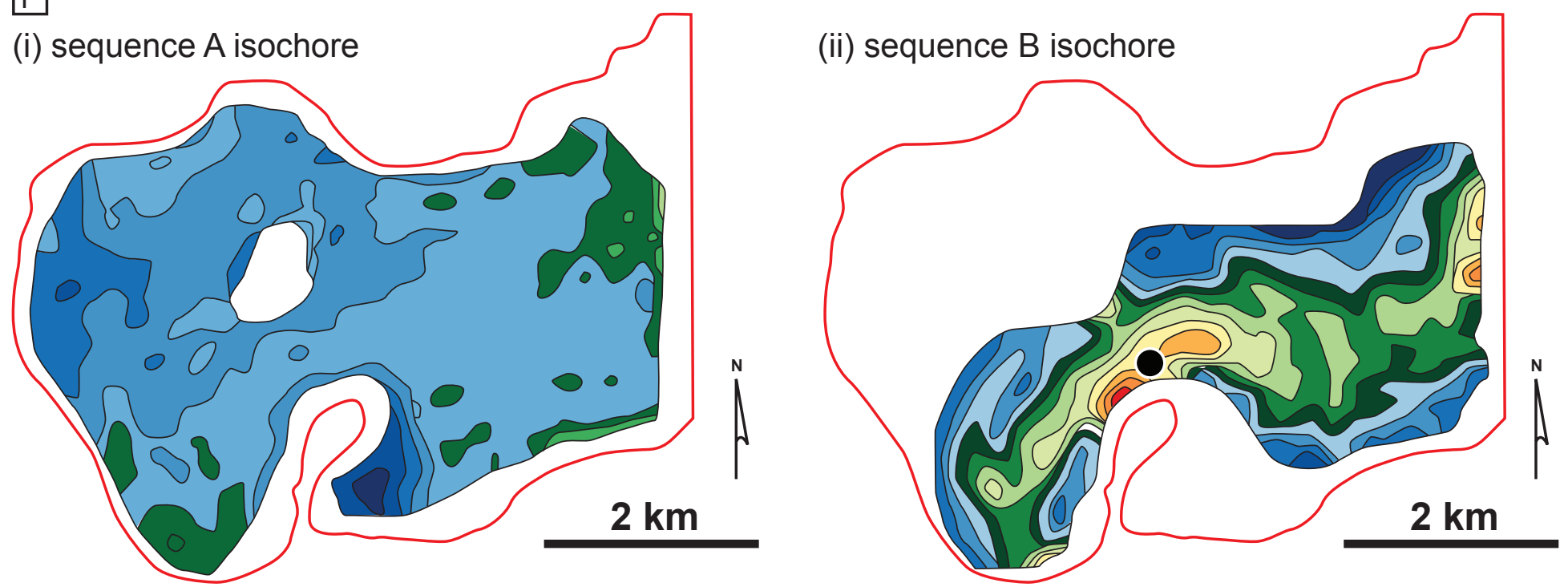

(iii) sequence $C$ isochore

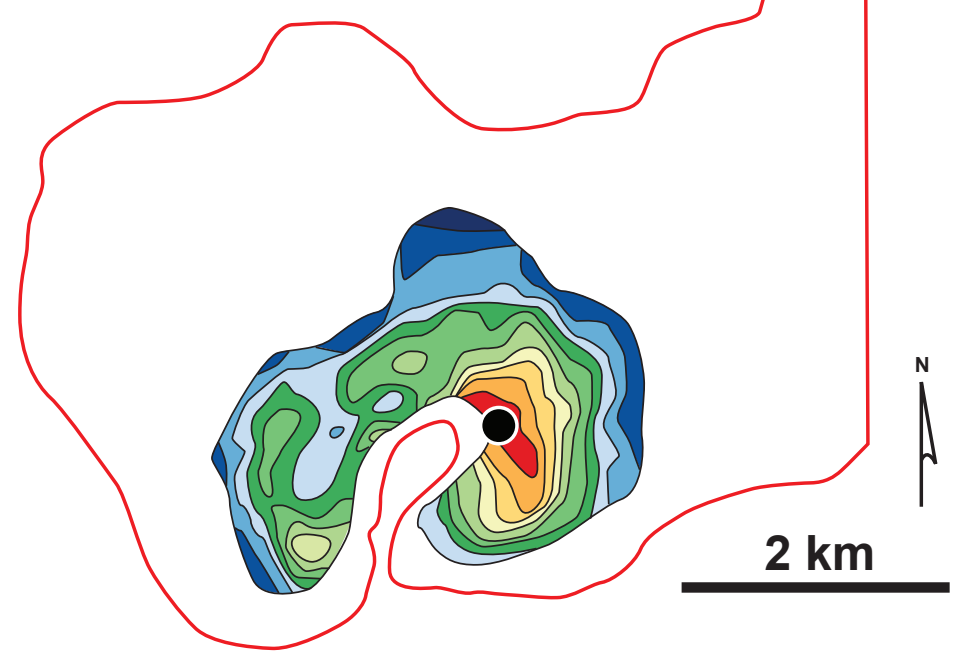

(iv) sequence $D$ isochore

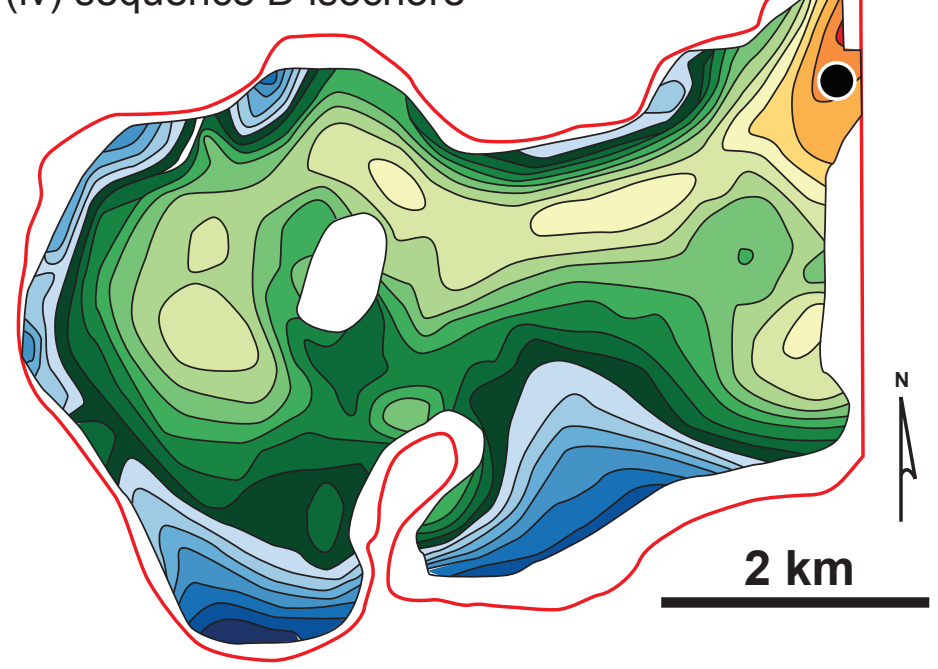



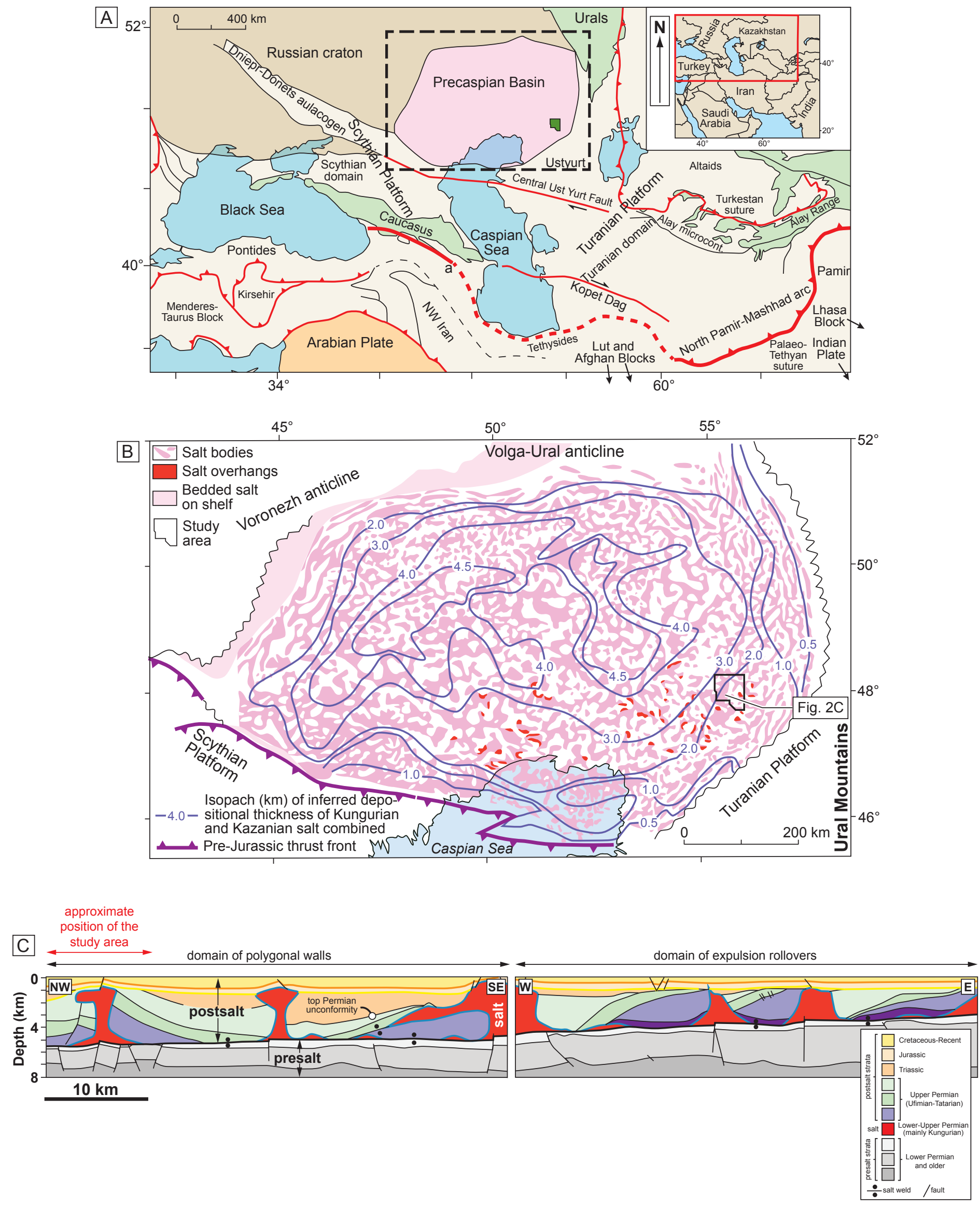
Fig. 3
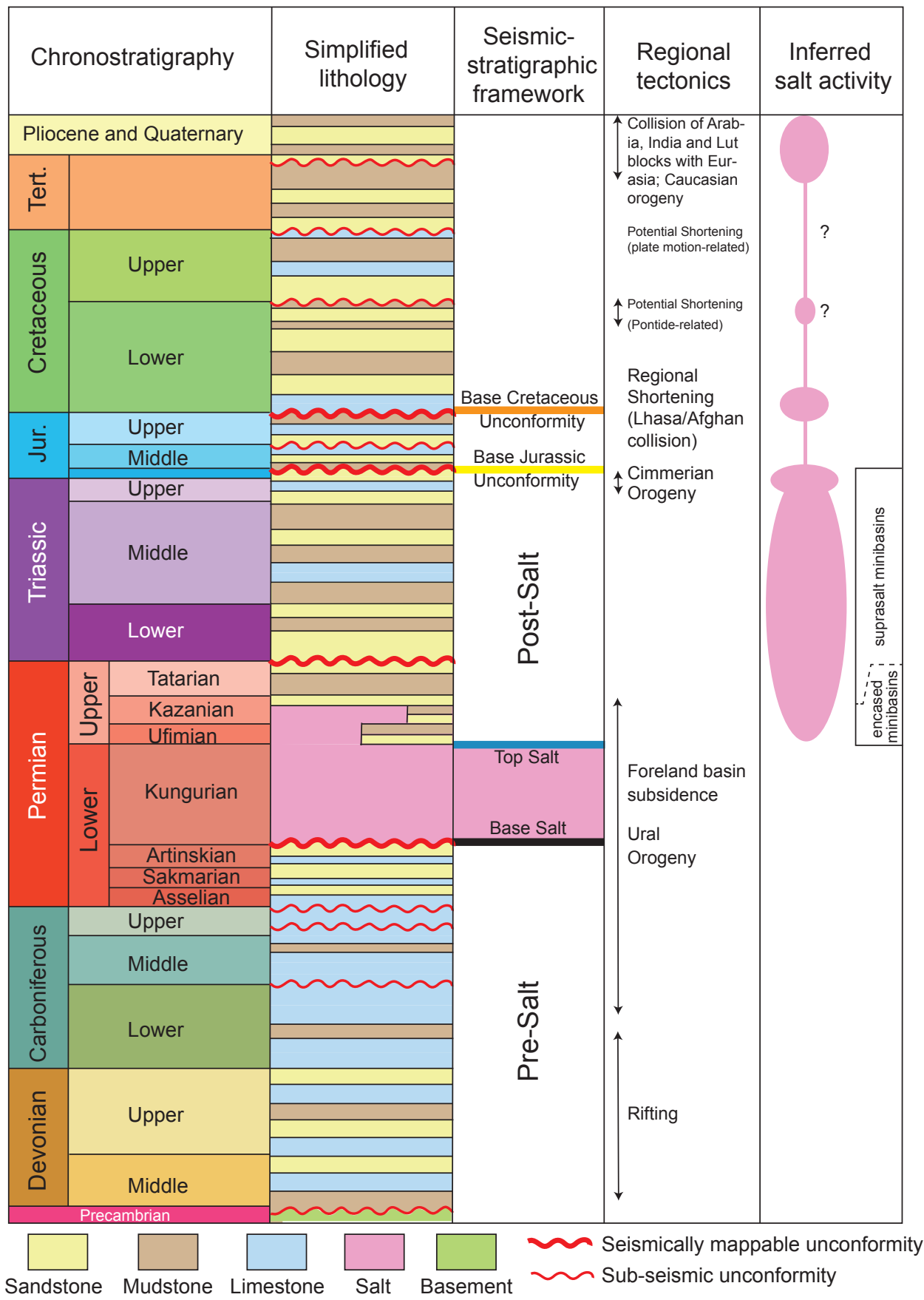

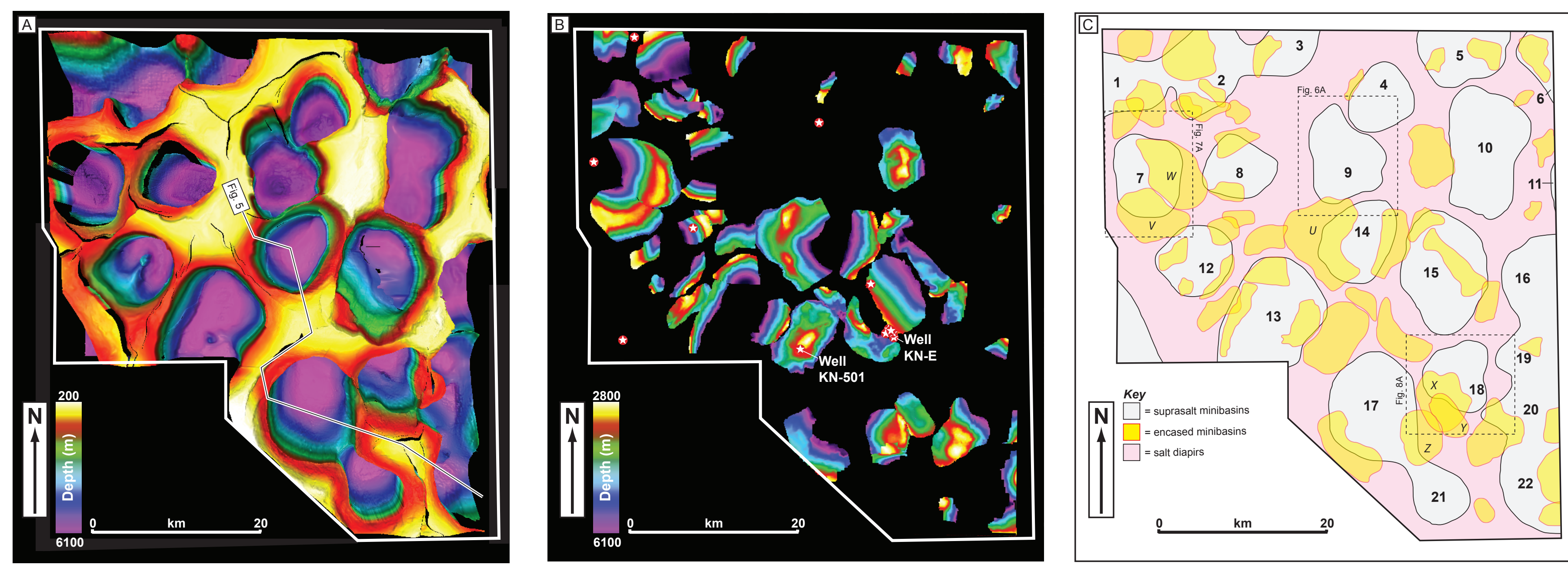
Fig. 5
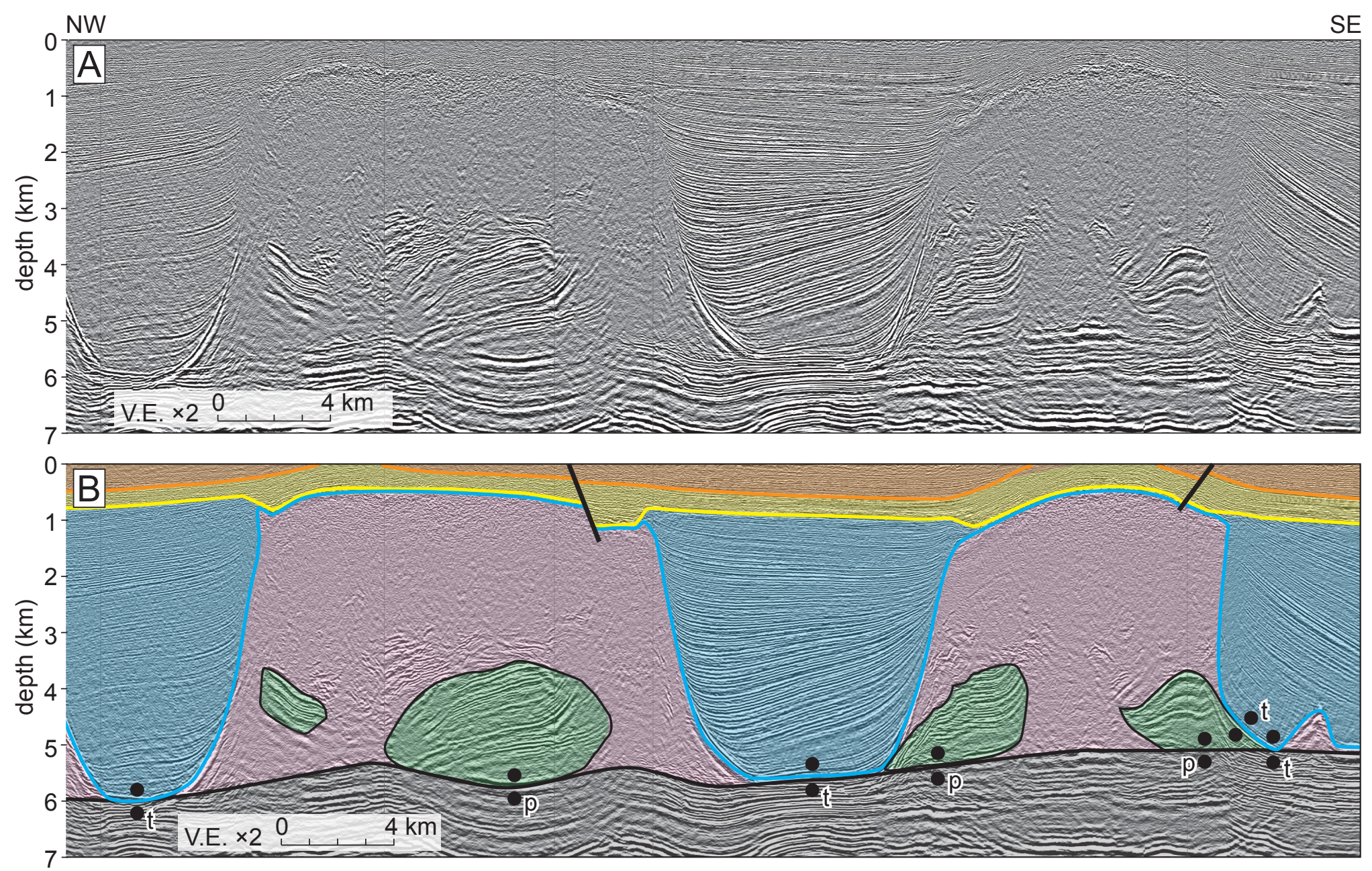

Key
$\square$ Cretaceous
$\square$ Jurassic
$\square$ Upper Permian-Upper Triassic (suprasalt minibasins)
$\square$ Upper Permian (encased minibasins)
$\square$ Lower to Upper Permian (salt)
$\square$ presalt


Fig. 6
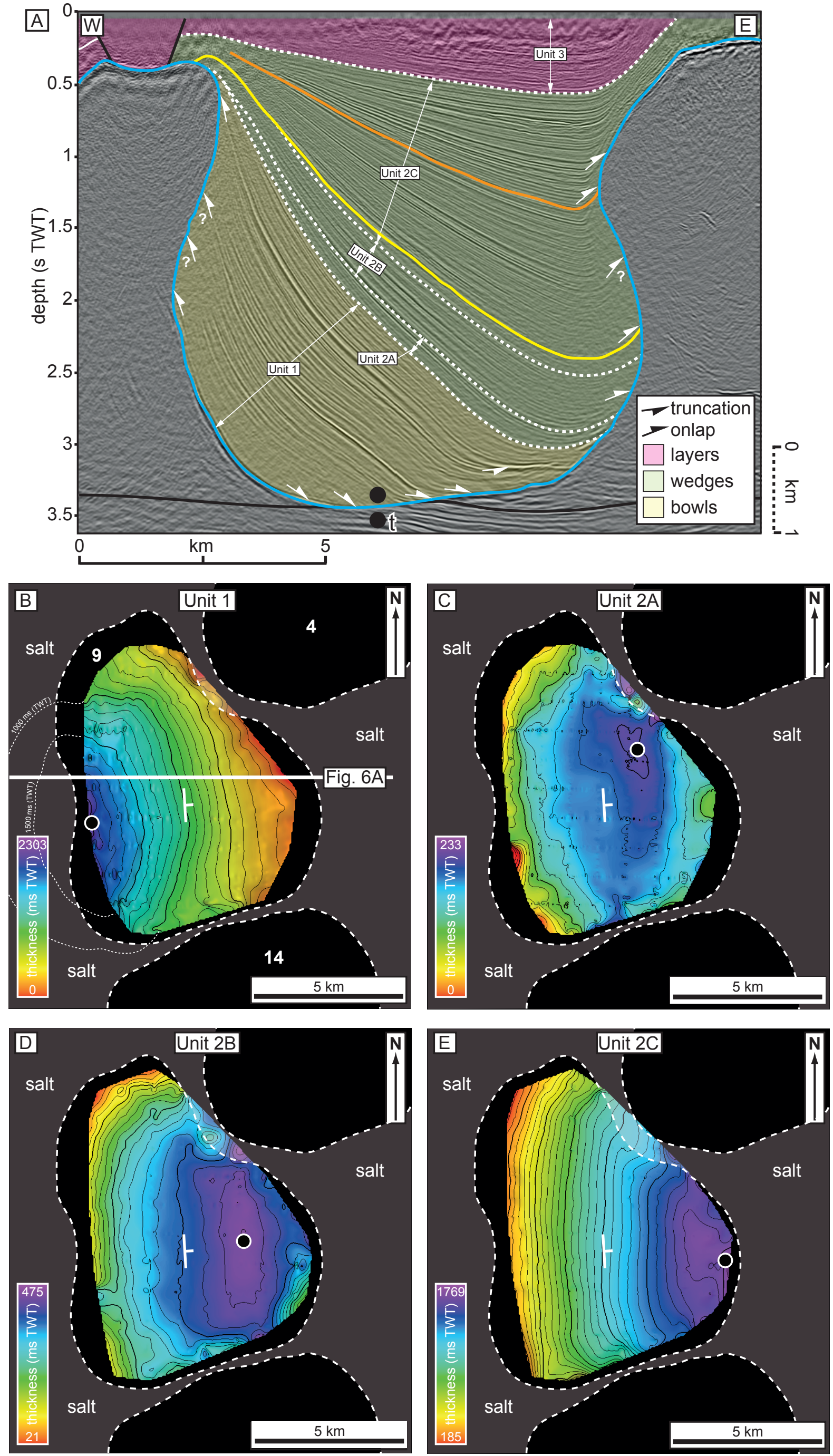
Fig. 7
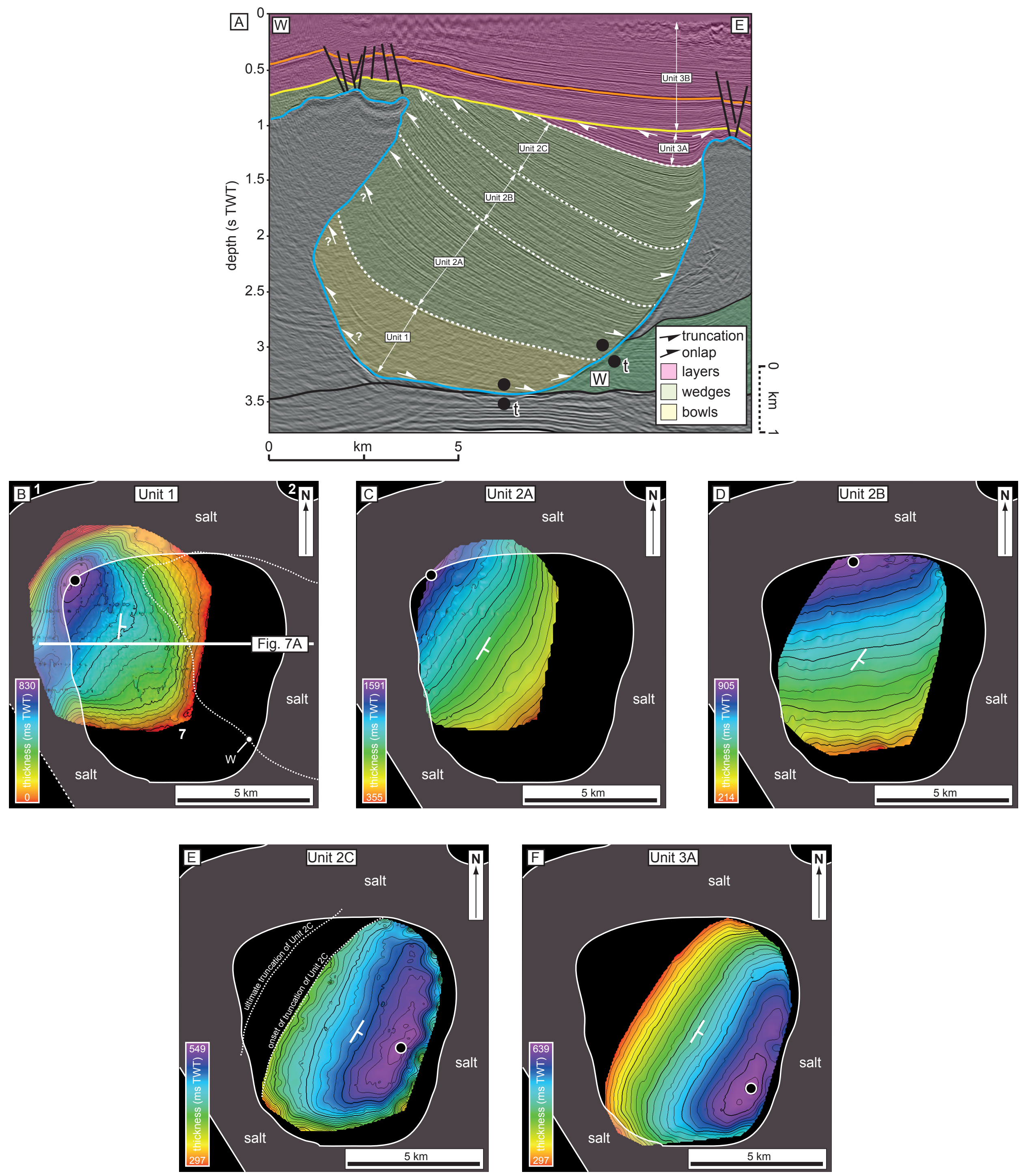
Fig. 8
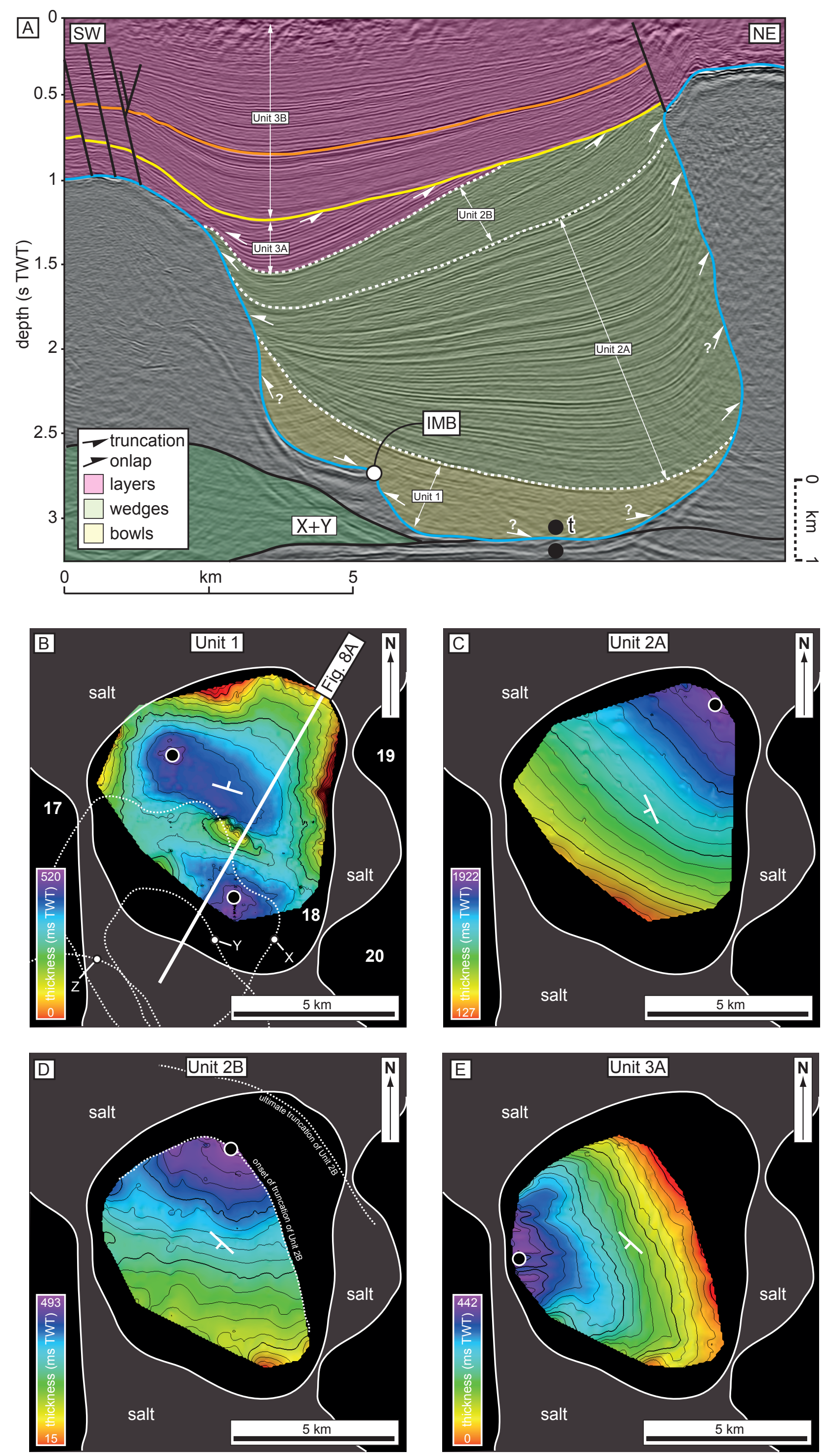
Fig. 9

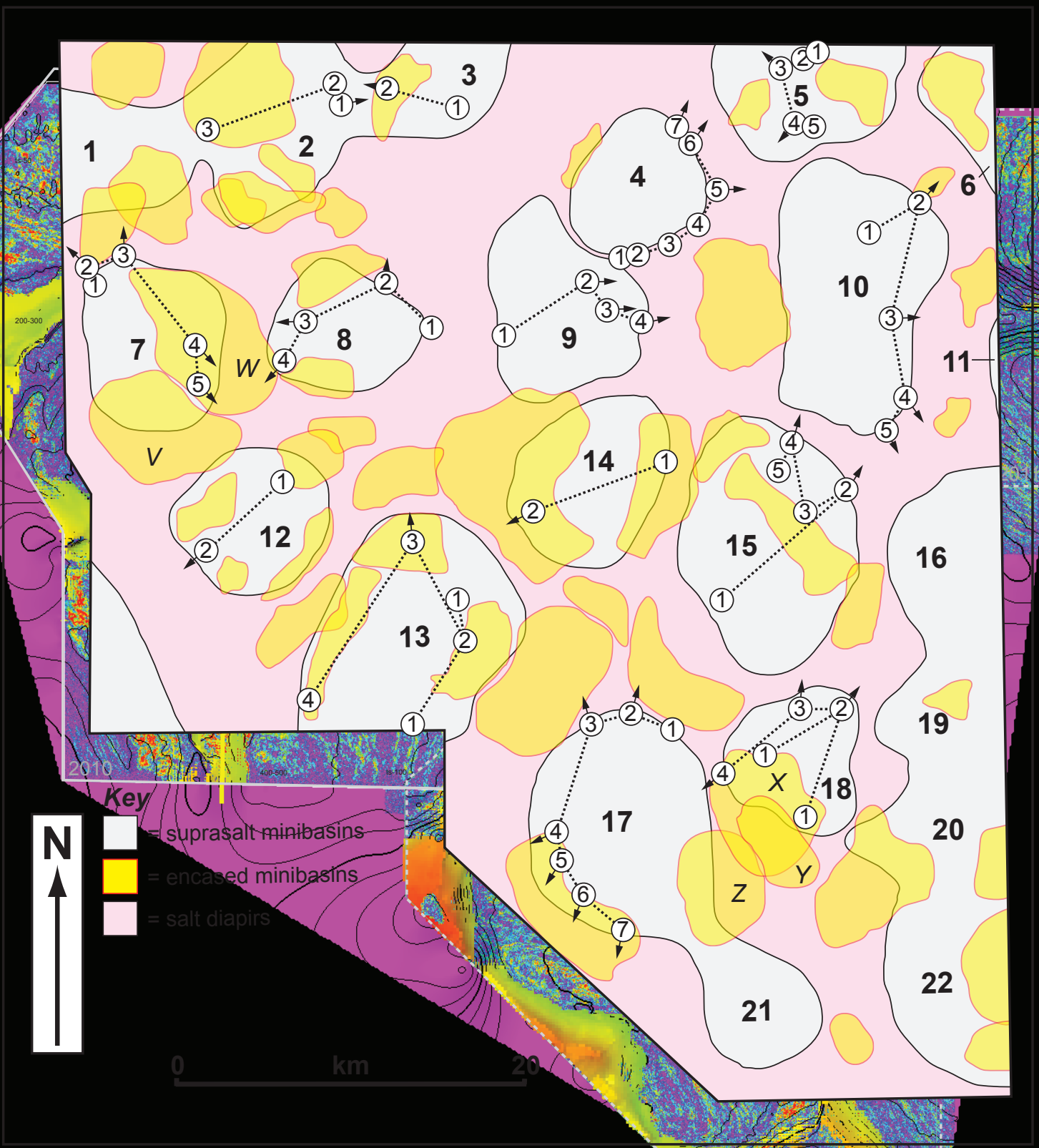


Fig. 10
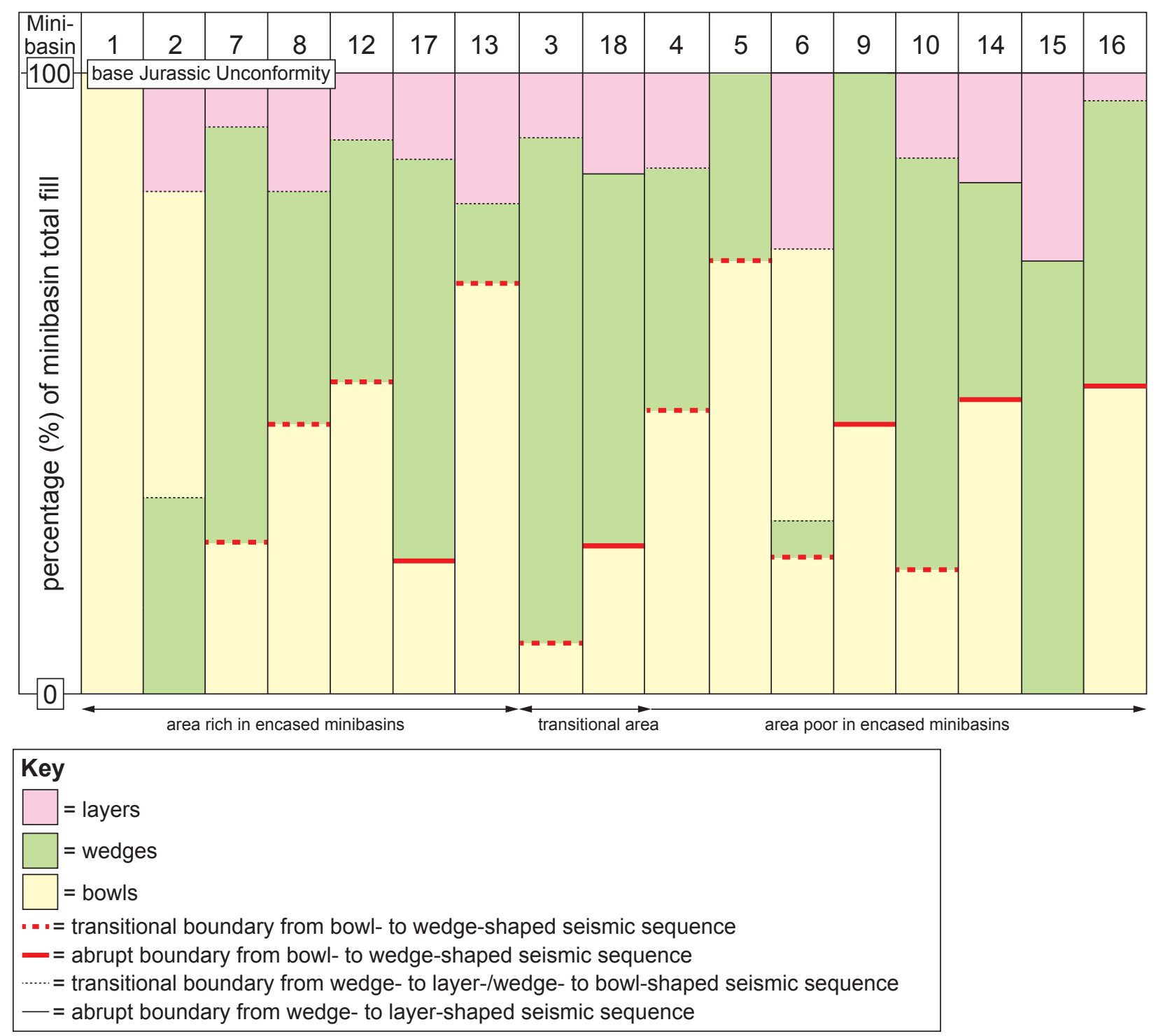
Fig. 11
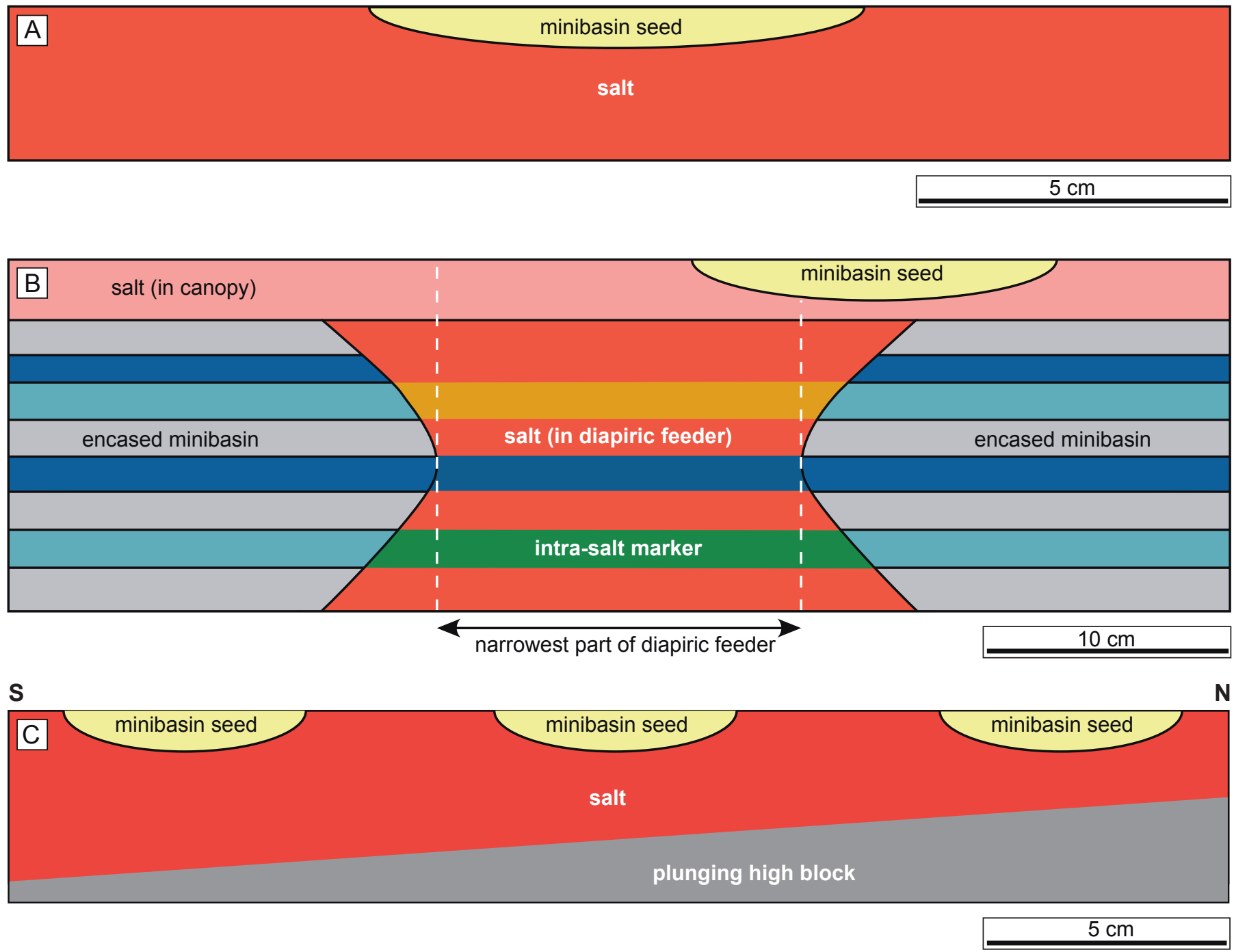
Fig. 12
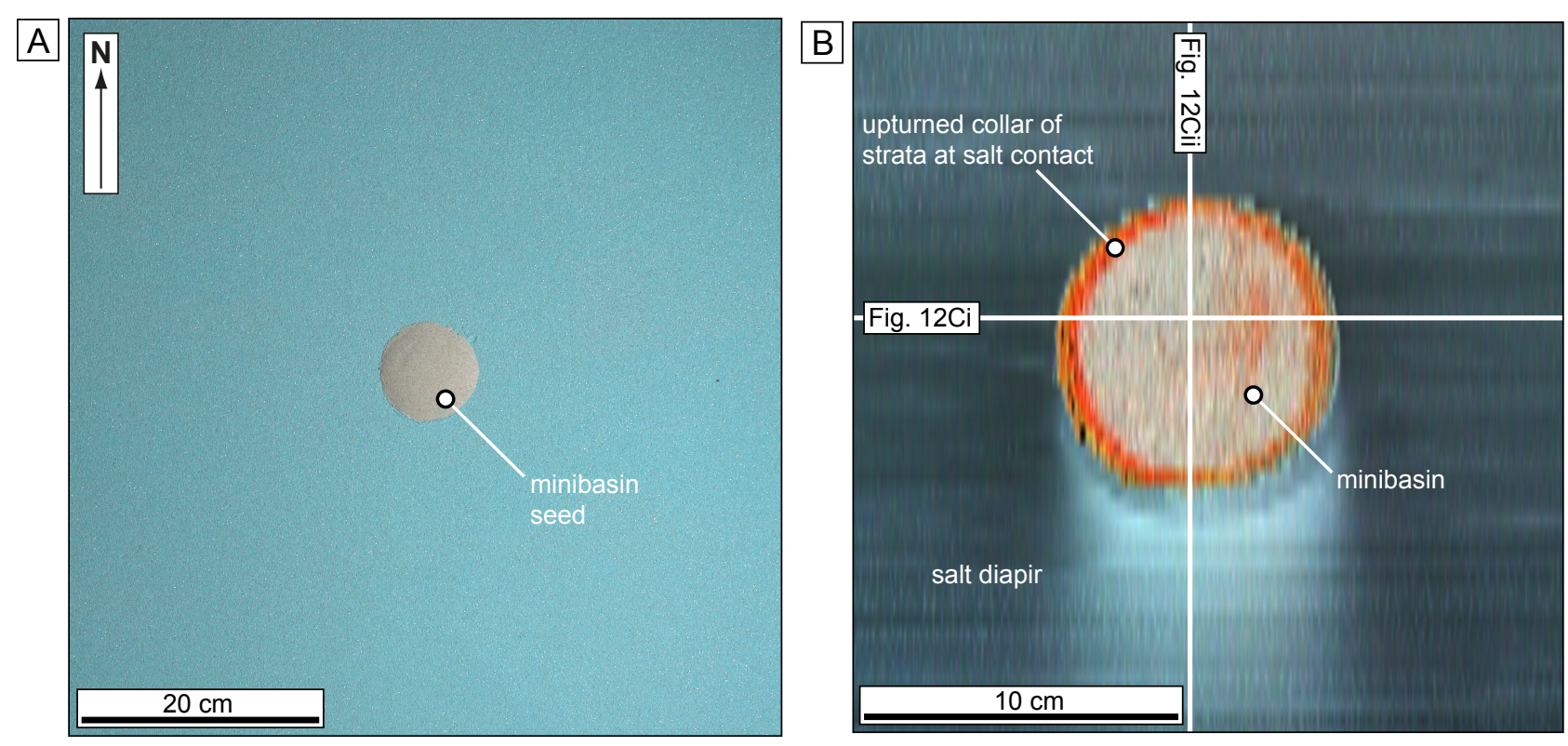

[Fig. 12Cii]
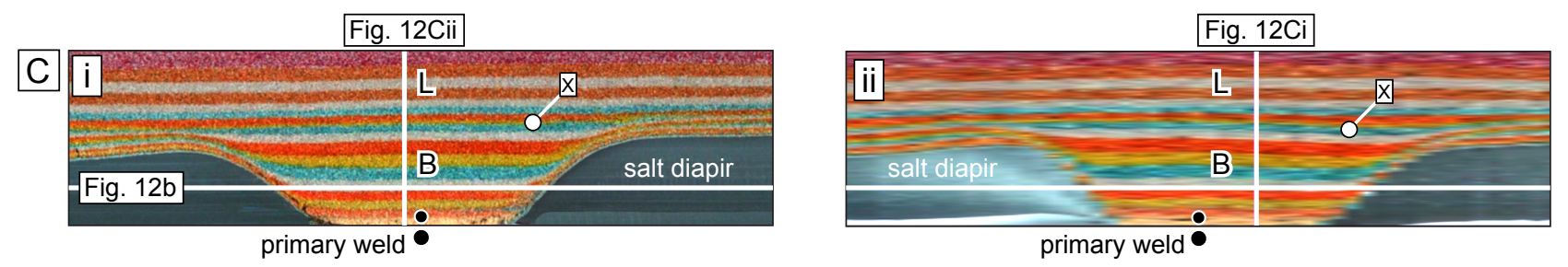
Fig. 13
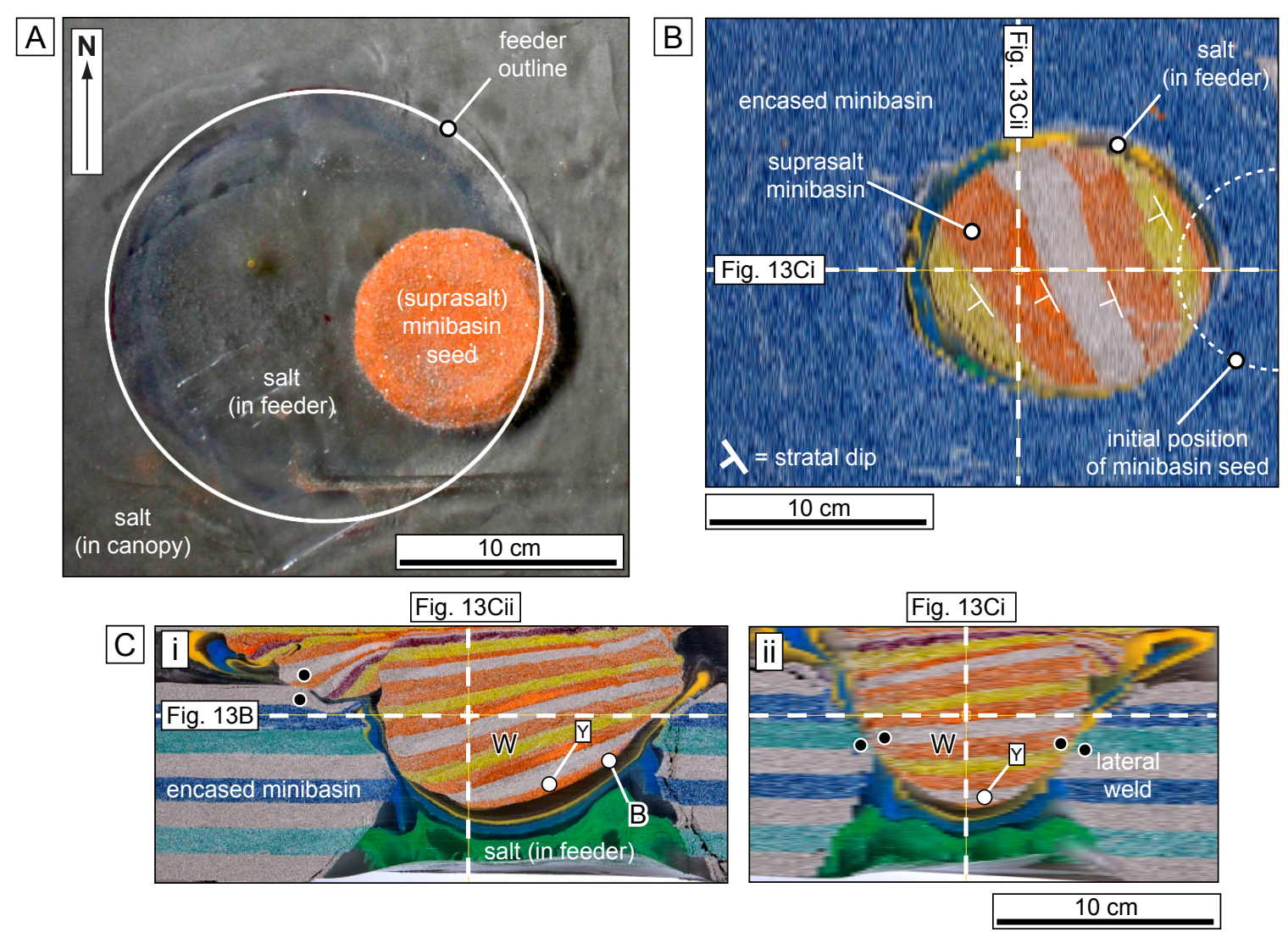
Fig. 14
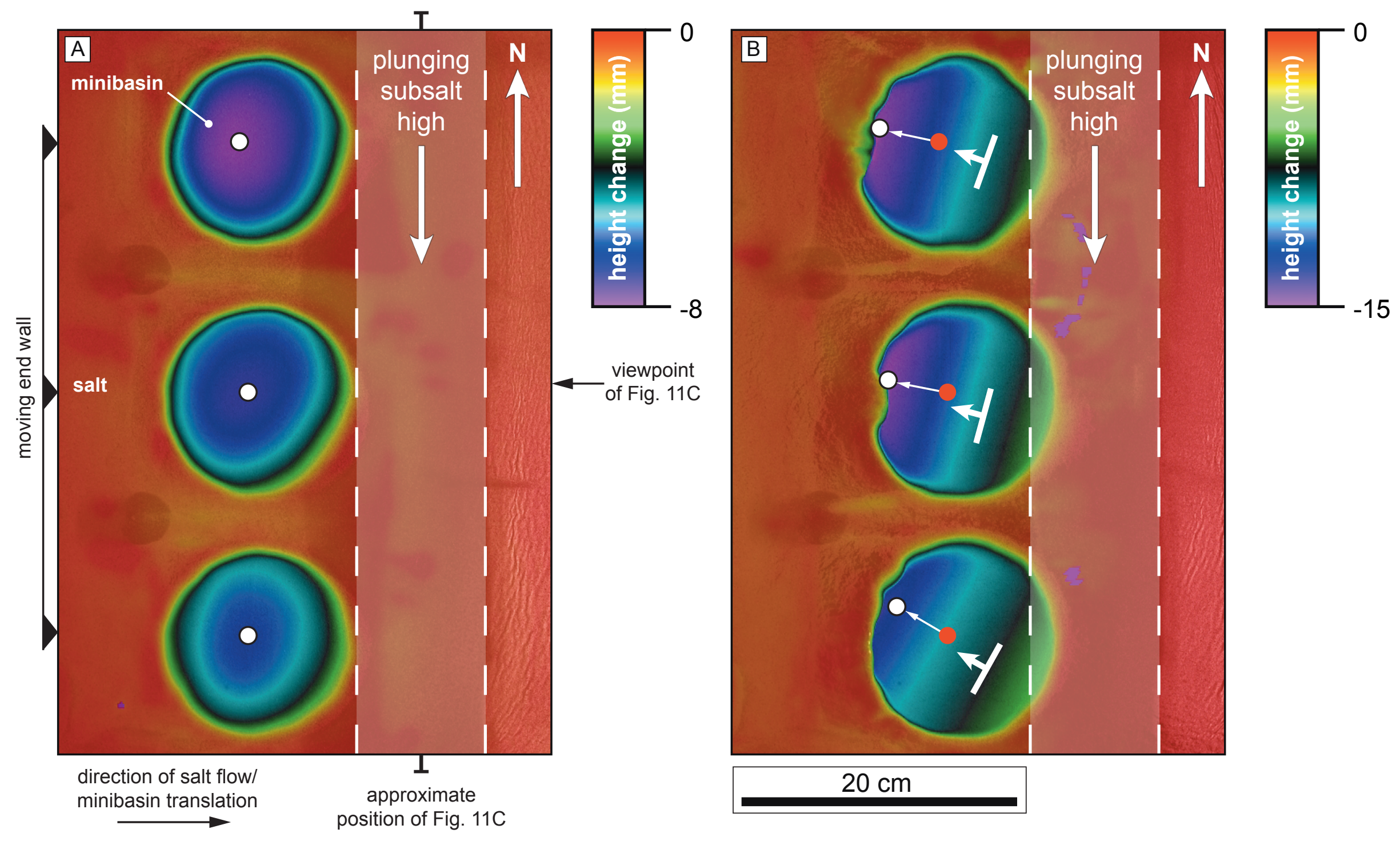
Fig. 15
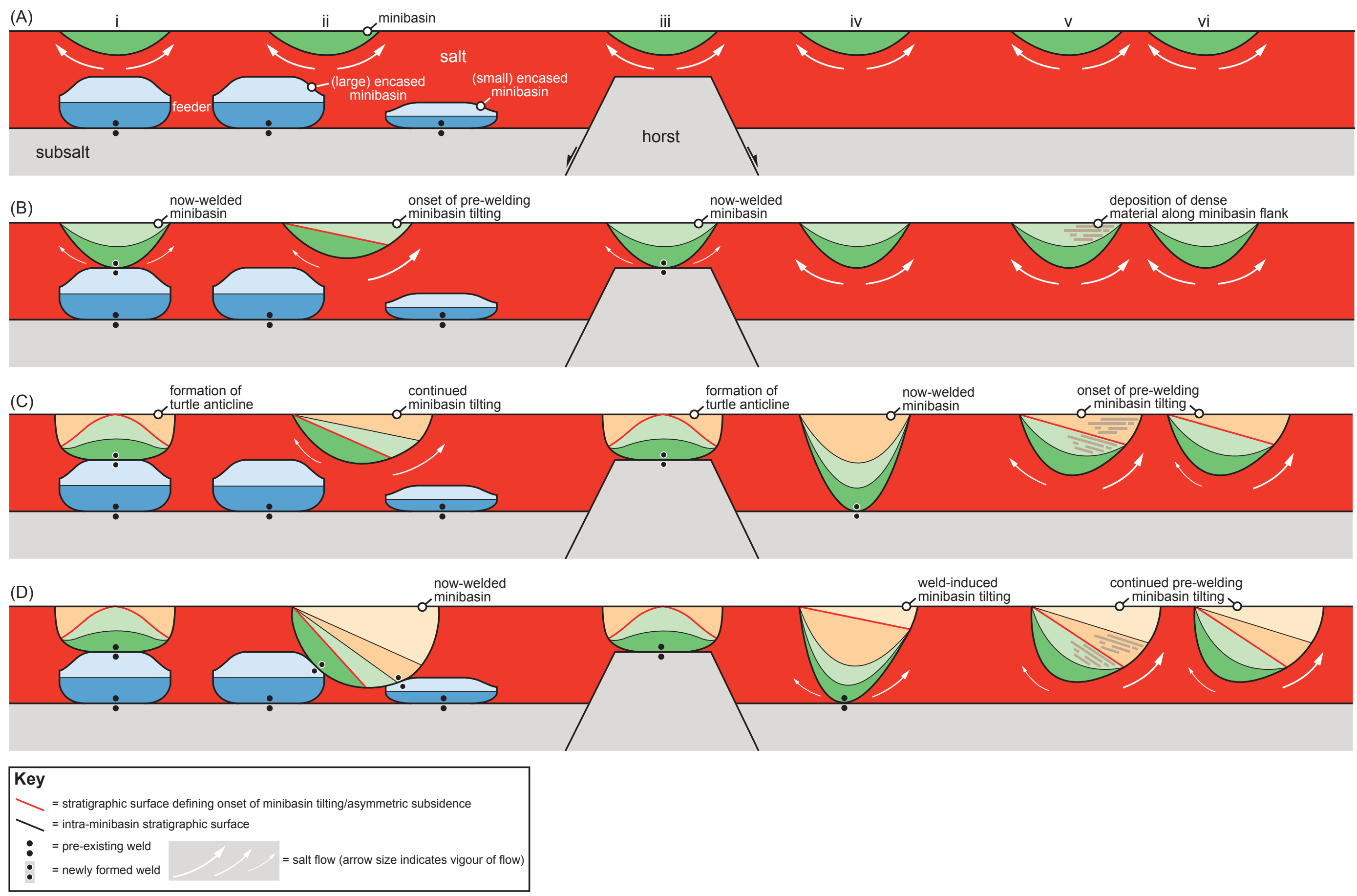